\title{
Highly fractionated I-type granites in NE China (I): geochronology and petrogenesis
}

\author{
Fu-yuan $\mathrm{Wu}^{\mathrm{a}, \mathrm{b}}$, Bor-ming Jahn ${ }^{\mathrm{b}, *}$, Simon A. Wilde ${ }^{\mathrm{c}}$, Ching-Hua Lo ${ }^{\mathrm{d}}$, Tzen-Fu Yui ${ }^{\mathrm{e}}$, \\ Qiang Lin ${ }^{\mathrm{a}}$, Wen-chun Ge ${ }^{\mathrm{a}}$, De-you Sun ${ }^{\mathrm{a}}$ \\ ${ }^{a}$ Department of Geology, Jilin University, 79 Jianshejie, 130061 Changchun, China \\ ${ }^{\mathrm{b}}$ Géosciences Rennes (CNRS), Université de Rennes I, Avenue du Géneral Leclerc, \\ F-35042 Rennes cedex, France \\ ${ }^{\mathrm{c}}$ School of Applied Geology, Curtin University of Technology, Perth, Western Australia, 6845, Australia \\ ${ }^{\mathrm{d}}$ Department of Geology, National Taiwan University, 245 Choushan Road, Taipei, 10770, Taiwan \\ ${ }^{\mathrm{e}}$ Institute of Earth Sciences, Academia Sinica, P.O. Box 1-55, Nankang, Taipei 11529, Taiwan
}

Received 25 January 2001; accepted 18 September 2002

\begin{abstract}
Northeastern (NE) China is the easternmost part of the Central Asian Orogenic Belt (CAOB), which is celebrated for its accretionary tectonics and the world's most important juvenile crust production in the Phanerozoic era. Abundant granitoids occur in the Great Xing'an, Lesser Xing'an and Zhangguangcai Ranges in NE China. This paper presents partial results of a series of studies on the granitoids from this region, aiming to understand their role in the building of new continental crust in eastern Asia. Three composite granite plutons (Xinhuatun, Lamashan and Yiershi) were chosen for geochemical and isotopic study in order to determine their emplacement ages and petrogenesis. Petrographically, they range from granodiorite (minor), monzogranite, syenogranite to alkali-feldspar granite. Quartz and perthitic feldspar are principal phases, accompanied by minor amounts of plagioclase, biotite $(<5 \%)$ and other accessory minerals. In addition, many contain abundant miarolitic cavities which suggest that they were emplaced at shallow levels with extensive fractional crystallization. Geochemically, the granites are silica-rich, peraluminous and have high contents of alkalis. They invariably show enrichment in light rare earth elements (LREE) and significant negative Eu anomalies. All the granitic rocks demonstrate the characteristic negative anomalies in $\mathrm{Ba}, \mathrm{Nb}, \mathrm{Sr}, \mathrm{P}, \mathrm{Eu}$, and $\mathrm{Ti}$, and a positive anomaly in $\mathrm{Pb}$ in the spidergram.

The emplacement of the Xinhuatun pluton took place at $184 \pm 4 \mathrm{Ma}$ as revealed by zircon SHRIMP U-Pb data. This is also supported by the slightly younger $\mathrm{Rb}-\mathrm{Sr}$ whole-rock (WR) isochron age of $173 \pm 3 \mathrm{Ma}$. A whole-rock (WR) $\mathrm{Rb}-\mathrm{Sr}$ isochron age of $154 \pm 3 \mathrm{Ma}$ was obtained for the Lamashan pluton, which is interpreted as close to the time of emplacement. The Yiershi pluton was intruded at about $140 \mathrm{Ma}$ as evidenced by a zircon $\mathrm{U}-\mathrm{Pb}$ age of $137 \pm 2 \mathrm{Ma}$ and $\mathrm{WR} \mathrm{Rb}-\mathrm{Sr}$ isochron age of $143 \pm 5 \mathrm{Ma}$. Biotite-WR $\mathrm{Rb}-\mathrm{Sr}$ isochrons and ${ }^{40} \mathrm{Ar} /{ }^{39} \mathrm{Ar}$ ages of feldspars allow us to estimate the cooling rate of each pluton.

Geochemical data suggest that the rocks are highly fractionated I-type granites. Fractionation of biotite and feldspars was the principal process of magmatic differentiation and responsible for major element variation. $\mathrm{Rb}, \mathrm{Sr}$ and $\mathrm{Ba}$ concentrations
\end{abstract}

* Corresponding author. Tel.: +33-2-23-23-60-83; fax: +33-2-23-23-56-80.

E-mail address: jahn@univ-rennes1.fr (B. Jahn). 
were controlled by feldspar separation, whereas REE elements were fractionated by accessory minerals, such as apatite, allanite and monazite.

(C) 2002 Elsevier Science B.V. All rights reserved.

Keywords: NE China; Central Asian Orogenic Belt; Granite; I-type granite; Geochronology; Geochemistry

\section{Introduction}

Northeastern (NE) China is characterized by widespread Phanerozoic granitic rocks, which are traditionally regarded as of late Paleozoic ("Hercynian") age. According to regional geological surveys, the granites comprise at least $50 \%$ of the area in the mountainous regions (JBGMR, 1988;

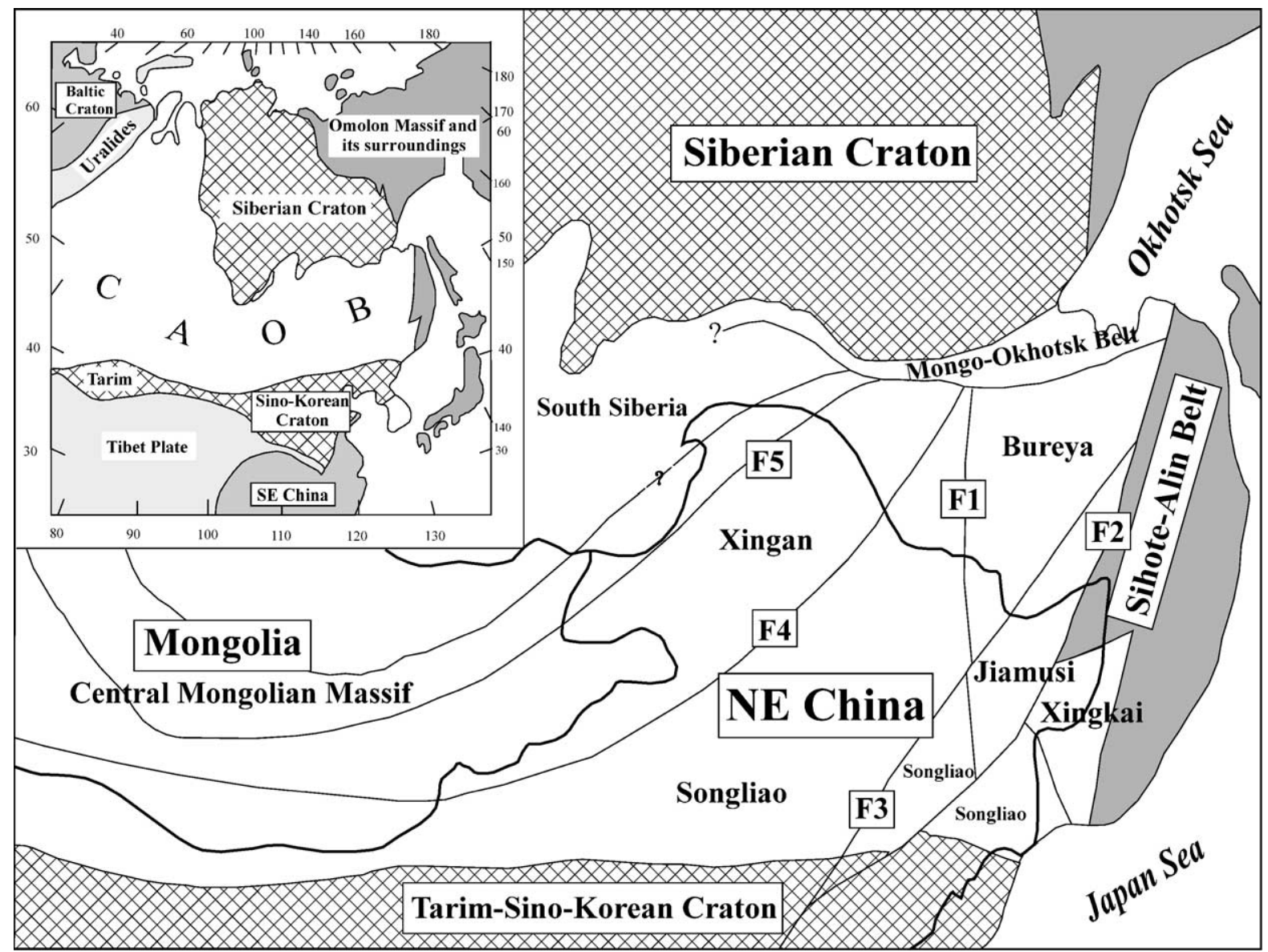

Fig. 1. Tectonic map of the Xingmeng (Xing'an-Mongolian) Orogenic Belt in the eastern part of the CAOB (Central Asian Orogenic Belt). The belt consists of several microcontinental blocks including the Jiamusi block and its northern extension in Bureya (Russia), the Songliao and Xing'an blocks, etc. All these blocks contain small proportions of Precambrian basement rocks. Major faults-F1: Mudanjiang fault, F2: Dunhua-Mishan Fault (northern branch of the Tanlu Fault), F3: Yitong-Jiamusi Fault, F4: Nenjiang-Hegenshan Fault, F5: DerbuganSouthern Mongolia Fault. 
HBGMR, 1993; IMBGMR, 1990), such as the Zhangguangcai Range in the east, Great Xing'an Range in the west and Lesser Xing'an Range in the north (Wu et al., 2000). Furthermore, underneath the flat-lying Songliao Basin, much of the basement is also composed of granites (Wu et al., 2001). Thus, NE China may be considered as a super-giant granitic province.

A few isotopic age data suggest several periods of granitic intrusions from early Paleozoic to Mesozoic (JBGMR, 1988; IMBGMR, 1990; HBGMR, 1993; Qin et al., 1998, 1999), but these results are published in Chinese journals or books, and thus not easily accessible. Moreover, our recent field and geochronological investigations indicate that the Paleozoic granites are only present in the Jiamusi Block in the east and in the Great Xing'an Range in the west (Wu et al., 2000, 2001, 2002); most other granites are of Mesozoic age.

The extensively exposed Mesozoic I- and A-type granitoids in NE China (almost 100,000 $\mathrm{km}^{2}$ ) are little known in the western literature. Several hundreds of plutons occur throughout the Xing'an and Songliao blocks (Fig. 1). Petrographically, they range from granodiorite (minor), monzogranite, syenogranite to alkali-feldspar granite and alkaline granite. Quartz and perthitic feldspar are the principal phases, accompanied by minor amounts of plagioclase, ferromagnesian and other accessory minerals. Mafic alkaline minerals, such as arfvedsonite and aegirine-augite, are found only in the alkaline granites. In addition, many contain abundant miarolitic cavities which suggest that they were generally emplaced at shallow levels with extensive fractional crystallization. Most granites contain biotite $(<5 \%)$ as the only mafic mineral. Mafic enclaves are rare. The generation of this kind of fractionated granite has rarely been studied (Champion and Chappell, 1992).

Though the Phanerozoic granites are widespread in NE China, few of them have been precisely dated. The absence of good age data hampers our understanding of the time-space relationship of the massive distribution of granitic rocks in NE China. In this paper, we present new $\mathrm{U}-\mathrm{Pb}, \mathrm{Rb}-\mathrm{Sr}$ and $\mathrm{Ar}$ isotopic age data for three plutons of felsic I-type granites to determine their emplacement histories and cooling rates. In the companion paper (part II), $\mathrm{Sr}-\mathrm{Nd}-\mathrm{O}$ isotopic and trace element data will be presented to constrain their petrogenesis; some important implications for the continental crustal growth in the Phanerozoic will be discussed.

\section{Geological setting}

The study area is traditionally considered as the eastern segment of the Xingmeng Orogenic Belt (Xingmeng $=$ Xing' an and Mongolia or KhinganMongolian), which constitutes the eastern part of the Central Asian Orogenic Belt (CAOB, Fig. 1). NE China represents a collage of three microcontinental blocks (Ye et al., 1994; Wu et al., 1995): the Jiamusi Block in the east, Songliao Block in the centre and Xing'an Block in the northwest (Fig. 1). The three blocks are separated by the Mudanjiang (F1) and Nenjiang (F4) faults. Distinct geological characteristics and geophysical properties separate the individual blocks (Ye et al., 1994).

The Jiamusi Block is characterized by two sequences of Precambrian metamorphic rocks - the Mashan and Heilongjiang Groups. The Mashan Group comprises granulite, marble, graphitic schist (of khondalitic affinity), together with gneiss and garnet-bearing granite. It was metamorphosed to the granulite facies $500 \mathrm{Ma}$ ago (Wilde et al., 1997, 2000). The Heilongjiang Group, exposed along the Mudanjiang Fault between the Jiamusi and Songliao Blocks, is characterized by highly deformed blueschist facies rocks including glaucophane schist, marble and chert.

The Songliao Block is mostly restricted by the Songliao sedimentary basin. Its eastern and northern parts are the Zhangguangcai and Lesser Xing'an Ranges which are characterised by voluminous Phanerozoic granitic rocks. Proterozoic metamorphic rocks with banded iron formations (Dongfengshan Group) occur in the eastern Lesser Xing'an and northern Zhangguangcai Ranges, where a change from a passive continental margin in the Cambrian to an active margin in the Silurian has been identified (HBGMR, 1993). Recent borehole data from the Songliao Basin reveal that granites are widespread and form the basement of the basin (Wu et al., 2001).

The Xing'an Block, located in the Great Xing'an Range, is characterized by extensive Mesozoic vol- 
canic and granitic rocks. Proterozoic metamorphic rocks also occur in the northern part, and Paleozoic strata are well developed, especially in the southern part.

A tectonic affinity between the Xing'an block and the Siberia continent or the Central Mongolian Massif has been suggested based on paleomagnetic data (Zonenshain et al., 1990). However, the origin of the Songliao and Jiamusi blocks remains controversial (Tang et al., 1995). According to Zonenshain et al. (1990), these two blocks constitute part of the Khingan-Bureya Massif, which is distinguished in its tectonic evolution from Siberia and other adjacent cratons.

The assemblage of the Jiamusi and Songliao blocks probably took place in the Silurian based on several lines of evidence: (1) identification of an Ordovician arc assemblage on the eastern margin of the Songliao block; (2) occurrence of blueschists with metamorphic ages of ca. 600-560 Ma (Zhang, 1992); (3) an ophiolitic melange in which middle OrdovicianSilurian radiolaria-bearing siliceous rocks occur along the Mudanjiang Fault; (4) intrusion of calc-alkaline granites at 435-400 Ma (HBGMR, 1993); and (5) deposition of Devonian shallow-water sedimentary rocks. The Jiamusi-Songliao composite block was then accreted to the Xing'an block along the Nenjiang fault during the late Devonian to early Carboniferous (Ye et al., 1994; Yu et al., 1996), followed by development of a regional extensional system (Tang, 1990; Wu et al., 1995).

A major controversy concerns the timing of collision between the North China Block (NCB) and the composite Xingmeng Block (now the eastern part of the Central Mongolian microcontinent). It has been suggested that collision took place in the late Triassic (Zonenshain et al., 1985, 1990), but recent paleomagnetic data suggest that the Xingmeng and the NCB were amalgamated before the late Permian, and then collided with the Siberian plate when the MongoliaOkhotsk Ocean was closed in the late Jurassic (Zhao et al., 1990).

In the Xingmeng belt, available age data indicate three distinct periods of granite magmatism: (1) late Paleozoic (300-250 Ma), with emplacement of calcalkaline rocks (diorite, tonalite and granodiorite) and late A-type granites (Hong et al., 1994; HBGMR, 1993; Wu et al., 2000, 2001, 2002; Sun et al., 2001);
(2) Triassic to Jurassic, with highly fractionated I- and A-type granitoids (in $\mathrm{Wu}$ et al., 2002 and to be discussed below); and (3) Cretaceous, with I-type granites (granodiorite, monzogranite and syenite), followed by A-type granites ( $\mathrm{Li}$ and $\mathrm{Yu}, 1993$; Wang and Zhao, 1997; Jahn et al., 2001; Wu et al., 2002). The Mesozoic A-type granites are typically anorogenic, and are genetically related to extension in eastern China during the Yanshan Orogeny (JurassicCretaceous, HBGMR, 1993).

\section{Sample description}

Representative rock types were selected from three plutons (Xinhuatun, Lamashan and Yiershi) for geochemical and isotopic studies (Fig. 2). These plutons were previously considered to be the most typical Triassic granites in NE China (HBGMR, 1993), and there is a need to verify their emplacement ages and to study their petrology and petrogenesis. The samples were taken from the freshest outcrops available at each locality. However, most samples still show effects of weathering and, in some instances, hydrothermal alteration as indicated by sericitization of feldspar and partial chloritization of biotite. Lithologic classification of the analyzed granites is based on the visually estimated modes in hand specimens and in thin sections (Table 1), as well as from chemical analyses (Table 2).

\subsection{Xinhuatun (samples prefixed with $X$-)}

The Xinhuatun pluton is located about $60 \mathrm{~km}$ to the east of Harbin, capital of Heilongjiang Province (Fig. 2a), and has an outcrop area of ca. $160 \mathrm{~km}^{2}$ (Fig. 2b). It is intruded into Upper Paleozoic-Lower Mesozoic strata, and covered by late Mesozoic volcanic and clastic sedimentary rocks. The rock types range from granodiorite, monzogranite to syenogranite, and they consist mainly of quartz, perthite and plagioclase with minor amount of biotite. In some cases, banding of the rock results from distinct biotite layers. Biotite-bearing rock corresponds to granodiorite which contains plagioclase phenocrysts and shows a hypidiomorphic-granular texture. The accessory mineral assemblage is magnetite, apatite, zircon, monazite and titanite. With a decreasing 


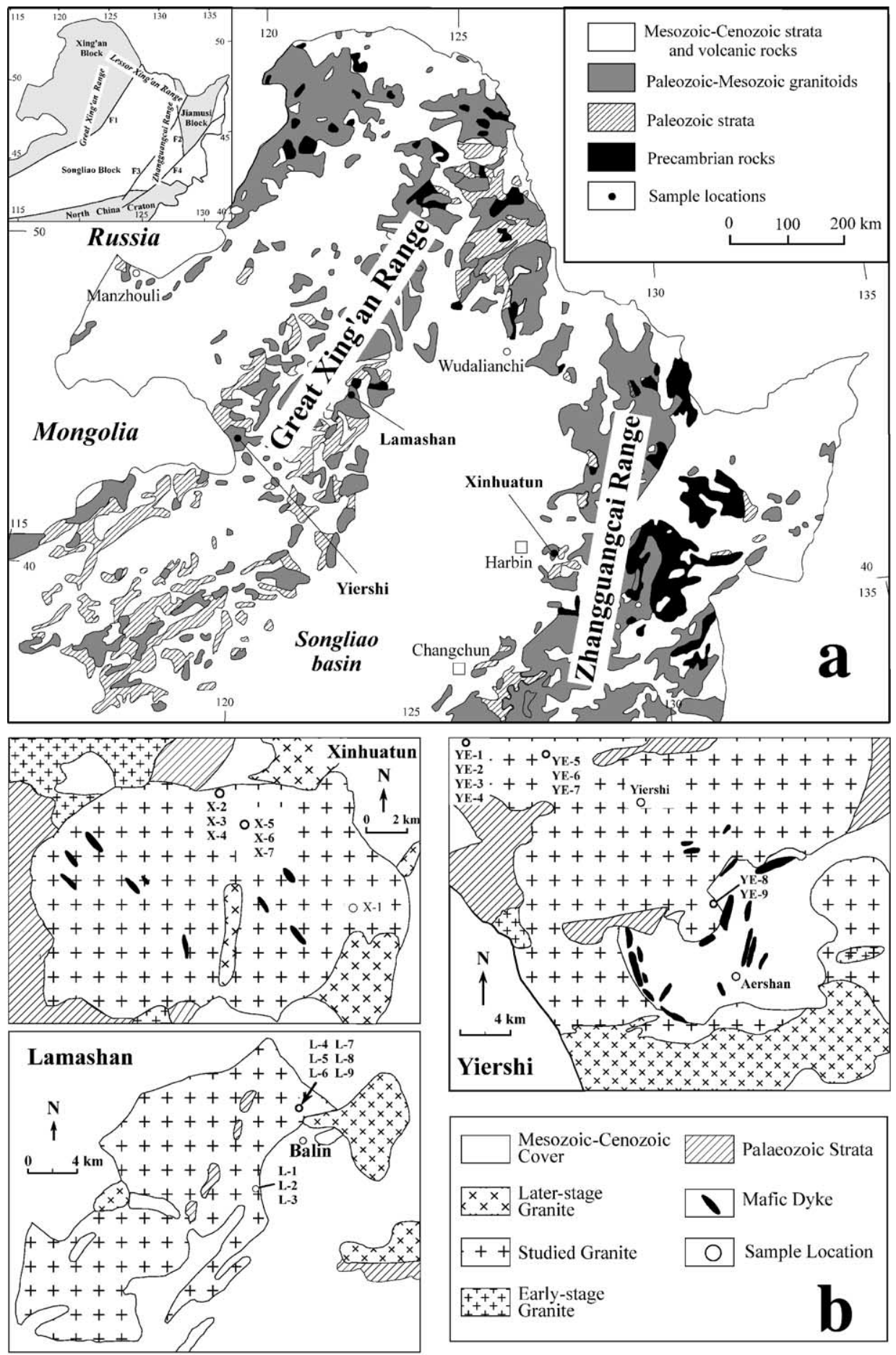

Fig. 2. Simplified geological map of NE China showing the sampling localities in the Xinhuatun, Lamashan and Yiershi granitic plutons. Xinhuatun is situated in the Zhangguangcai Range in the east, whereas the other two plutons are in the Great Xing'an (Khingan) Range in the west. The Songliao Basin separates both ranges. 
Table 1

The description of studied granitic samples in NE China

\begin{tabular}{|c|c|c|c|c|c|c|c|c|}
\hline Pluton & Sample No. & Rock type & Texture & $\mathrm{Bi}$ & Q (\%) & $\mathrm{Kf}(\%)$ & Pl (\%) & Note \\
\hline \multirow[t]{8}{*}{ Xinhuatun } & $\mathrm{X}-1$ & Syenogranite & Coarse & Trace (altered) & 20 & 70 & 10 & Zoned Pl \\
\hline & $X-2$ & Adamellite & Medium & $5 \%$ & 25 & 30 & 40 & Banded Bi \\
\hline & $\mathrm{X}-3$ & Granodiorite & Coarse & $10 \%$ & 20 & 10 & 60 & Banded Bi \\
\hline & & Kf granite & Fine & & 30 & 70 & & \\
\hline & $X-4$ & Granodiorite & Medium & $10 \%$ & 20 & 10 & 60 & Banded Bi \\
\hline & $X-5$ & Diorite enclave & Medium & $10 \%$ & 10 & & 80 & \\
\hline & $X-6$ & Syenogranite & Medium & $5 \%$ & 30 & 50 & 15 & \\
\hline & $X-7$ & Kf granite & Medium & $2 \%$ & 35 & 58 & 5 & \\
\hline \multirow[t]{9}{*}{ Lamashan } & L-1 & Adamellite & Coarse & Trace & 30 & 35 & 35 & Miarolitic \\
\hline & L-2 & Adamellite & Coarse & Trace & 30 & 40 & 30 & Miarolitic \\
\hline & L-3 & Adamellite & Coarse & Trace & 20 & 40 & 40 & Miarolitic \\
\hline & L-4 & Syenogranite & Coarse & Trace & 40 & 50 & 10 & Miarolitic \\
\hline & L-5 & Kf granite & Coarse & Trace & 30 & 65 & 5 & Miarolitic \\
\hline & L-6 & Syenogranite & Coarse & Trace & 30 & 60 & 10 & Miarolitic \\
\hline & L-7 & Syenogranite & Coarse & Trace & 40 & 50 & 10 & Miarolitic \\
\hline & L-8 & Syenogranite & Coarse & Trace & 40 & 50 & 10 & Miarolitic \\
\hline & L-9 & Kf granite & Fine & Trace & 50 & 45 & 5 & Miarolitic \\
\hline \multirow[t]{9}{*}{ Yiershi } & YE-1 & Kf granite & Coarse & Trace (altered) & 30 & 70 & & Granophyric \\
\hline & YE-2 & Kf granite & Fine & Trace (altered) & 30 & 70 & & Granophyric \\
\hline & YE-3 & Syenogranite & Coarse & Trace & 30 & 60 & 10 & \\
\hline & YE-4 & Kf granite & Medium & Trace & 30 & 70 & & Granophyric \\
\hline & YE-5 & Syenogranite & Coarse & $5 \%$ & 30 & 50 & 15 & \\
\hline & YE-6 & Kf granite & Fine & Trace (altered) & 30 & 65 & 5 & Aplitic \\
\hline & YE-7 & Kf granite & Fine & Trace (altered) & 30 & 65 & 5 & Aplitic \\
\hline & YE-8 & Kf granite & Medium & Trace (altered) & 30 & 70 & & \\
\hline & YE-9 & Syenogranite & Coarse & $5 \%$ & 35 & 50 & 10 & \\
\hline
\end{tabular}

amount of biotite, the rock changes from granodiorite, to monzogranite, syenogranite and finally to granophyre. This suggests that this pluton has undergone significant fractional crystallization. Hexagonal quartz is present in monzogranite and syenogranite, and small microgranular enclaves containing acicular crystals of apatite are also present.

\subsection{Lamashan (prefixed with L-)}

The Lamashan pluton, located in the Great Xing'an Range, crops out over $25 \mathrm{~km}^{2}$ (Fig. 2). It is intruded into older granites (Paleozoic?) and covered by Jurassic volcanic rocks. It has been considered as a typical pluton emplaced during the late Paleozoic (HLBMR, unpublished), but no precise age data are available. The pluton is made up mainly of medium- to coarse-grained granitoids, including monzogranite, syenogranite and alkali-feldspar granite. Locally, they are cut by centimetre- to decimetre-wide veins of fine-grained, grey alkali- feldspar granite and granophyre. Most of the granitic rocks show miarolitic cavities, and the late-stage granophyre displays a graphic texture. The major mineral phases are perthite, quartz and plagioclase. The Lamashan granites are distinguished from the Xinhuatun pluton by the small amount of biotite and presence of hexagonal quartz in all the rock types. Mafic enclaves are rare. The graphic texture and hexagonal quartz are indicative of shallow emplacement.

\subsection{Yiershi (prefixed with YE-)}

The Yiershi pluton $\left(\approx 400 \mathrm{~km}^{2}\right)$ occurs near the border of China and Mongolia (Fig. 2). It is intruded into Paleozoic sediments and cut by late-stage dikes and covered by Late Mesozoic volcanic rocks. The rock types range from medium- to coarse-grained syenogranite, alkali-feldspar granite and miarolitic granite in the early stage, to fine-grained granite in the late stage. The granite is made up principally of 
quartz and perthite, with plagioclase less than $15 \%$. In contrast, in the late-stage fine-grained granite, the alkali-feldspar often displays a thin albitic rim. Primary biotite is generally lacking, except in earlier intrusive phases, quartz is hexagonal in most cases, but feldspars (mostly alkali-feldspar) are subhedral to anhedral. In some cases, intergrowth of quartz and feldspar forms the graphic texture. The main accessory phases are apatite, magnetite, allanite and zircon.

\section{Analytical techniques}

\subsection{Major and trace elements}

Major and trace element (except rare earth elements) abundances were determined by X-ray fluorescence spectrometry (XRF) using a Philips PW1480 spectrometer at the Université de Rennes 1. Analytical uncertainties range from $1 \%$ to $3 \%$ for major elements; $5 \%$ for trace elements with concentrations $>20 \mathrm{ppm}$ and $10 \%$ for those $<20 \mathrm{ppm}$. REE abundances were determined by the isotope dilution method using the routine procedures employed at Rennes (Jahn et al., 1996). Overall analytical uncertainties are 3\% for all rare earth elements. In order to demonstrate the reliability of the analytical results, six samples (two from each pluton) were further analyzed using the ICP-MS method in Nancy, France, which employed a method of sample dissolution including fusion of rock powder with lithium borate $\left(\mathrm{LiBO}_{2}\right)$ flux. The results of isotopic dilution and ICP-MS are in good agreement (Table 2), particularly for REE abundances.

\subsection{Zircon $\mathrm{U}-\mathrm{Pb}$ analyses}

Zircon crystals were extracted by crushing and use of a combination of heavy liquid and magnetic separation techniques. Individual crystals were handpicked and mounted, along with several pieces of the Curtin University standard (CZ3 - which has a conventionally measured ${ }^{206} \mathrm{~Pb} /{ }^{238} \mathrm{U}$ age of $564 \mathrm{Ma}$ (Pidgeon et al., 1994)), onto double-sided adhesive tape and enclosed in epoxy resin discs. The discs were polished, so as to effectively section the zircons in half, and then gold-coated.
$\mathrm{U}-\mathrm{Th}-\mathrm{Pb}$ analyses of the zircons were performed using the SHRIMP ion microprobe at Curtin University, following standard procedures described by Williams (1998) and Nelson (1999). Spot size ranged between 20 and $30 \mu \mathrm{m}$ and each analysis spot was rastered over $120 \mu \mathrm{m}$ for $5 \mathrm{~min}$ to remove any common $\mathrm{Pb}$ on the surface or contamination from the gold coating. The mass resolution used to measure $\mathrm{Pb} / \mathrm{Pb}$ and $\mathrm{Pb} / \mathrm{U}$ isotopic ratios ranged from 4770 to 5000 during three analytical session, and the $\mathrm{Pb} / \mathrm{U}$ ratios were normalised to those measured on the standard zircon $\left[\mathrm{CZ3}-\left({ }^{206} \mathrm{~Pb} /{ }^{238} \mathrm{U}=0.0914\right)\right]$. The error associated with the measurement of $\mathrm{Pb} / \mathrm{U}$ isotopic ratios for the standard, at 1 standard deviation, was $\sim 2 \%$ during each analytical run. The measured ${ }^{204} \mathrm{~Pb}$ values in the unknowns were similar to those recorded for the standard zircon and so common lead corrections were made assuming an isotopic composition of Broken Hill lead, since the common lead is considered to be mainly associated with surface contamination in the gold coating (Nelson, 1999). The ${ }^{206} \mathrm{~Pb} /{ }^{238} \mathrm{U}$ ages are considered to be the most reliable for concordant Phanerozoic zircons (Compston et al., 1992) because the low count rates on ${ }^{207} \mathrm{~Pb}$ result in large statistical uncertainties, making the ${ }^{207} \mathrm{~Pb} /{ }^{206} \mathrm{~Pb}$ and ${ }^{207} \mathrm{~Pb} /{ }^{235} \mathrm{U}$ ratios a less sensitive measure of age. Data reduction was performed using both the WAllead (Australian National University) and Krill 007 (P. D. Kinny, Curtin University) programs, applying the ${ }^{208} \mathrm{~Pb}$ correction, since there is little evidence of postcrystallization disturbance to the $\mathrm{U}-\mathrm{Pb}-\mathrm{Th}$ systems of the younger zircons. Errors on individual analyses are based on counting statistics and are at the $1 \sigma$ level. Errors on pooled analyses are quoted at $2 \sigma$ or $95 \%$ confidence.

\subsection{Sr isotopic analyses}

$\mathrm{Sr}$ isotopic data were obtained using the method described by Jahn et al. (1996). Sample dissolution was carried out in sealed Savillex beakers for at least 7 days until no visible residues were observed. The same procedure was repeated when residue was observed after the first dissolution. The absence or insignificant amount of REE-carrying refractory minerals, such as zircon or monazite in the residue after dissolution, is clearly demonstrated in Table 2. Mass analyses were performed using a 7-collector Finnigan 
Table 2

The chemical compositions of the highly fractionated granites from NE China

\begin{tabular}{|c|c|c|c|c|c|c|c|c|c|c|c|}
\hline \multirow{2}{*}{$\frac{\text { Analysis No. }}{\text { Sample No. }}$} & \multirow{2}{*}{$\begin{array}{l}12970 \\
X-1\end{array}$} & \multicolumn{2}{|l|}{12971} & \multicolumn{2}{|r|}{12972} & \multicolumn{2}{|l|}{12973} & \multicolumn{2}{|r|}{12974} & 12975 & 12976 \\
\hline & & $X-2$ & & & $\mathrm{X}-3$ & $X-4$ & & & $X-5$ & X-6 & $\mathrm{X}-7$ \\
\hline \multicolumn{12}{|c|}{ Major elements (wt.\%, by XRF) } \\
\hline $\mathrm{SiO}_{2}$ & 76.41 & \multicolumn{2}{|c|}{73.88} & & 76.54 & \multicolumn{2}{|l|}{68.91} & & 63.00 & 76.51 & 75.47 \\
\hline $\mathrm{Al}_{2} \mathrm{O}_{3}$ & 12.70 & \multicolumn{2}{|c|}{12.55} & & 12.45 & \multicolumn{2}{|l|}{13.45} & & 17.37 & 12.39 & 12.92 \\
\hline $\mathrm{FeO}^{*}$ & 0.62 & \multicolumn{2}{|c|}{2.19} & & 0.87 & \multicolumn{2}{|l|}{4.43} & & 3.89 & 0.74 & 0.69 \\
\hline $\mathrm{MnO}$ & 0.01 & \multicolumn{2}{|c|}{0.13} & & 0.05 & \multicolumn{2}{|l|}{0.28} & & 0.05 & 0.02 & 0.02 \\
\hline $\mathrm{MgO}$ & 0.08 & \multicolumn{2}{|c|}{0.61} & & 0.11 & 1.22 & & & 1.30 & 0.16 & 0.11 \\
\hline $\mathrm{CaO}$ & 0.43 & 0.51 & & & 0.44 & 1.10 & & & 2.54 & 0.49 & 0.45 \\
\hline $\mathrm{Na}_{2} \mathrm{O}$ & 3.70 & 3.12 & & & 3.88 & 3.93 & & & 5.67 & 3.74 & 3.49 \\
\hline $\mathrm{K}_{2} \mathrm{O}$ & 4.61 & 5.16 & & & 4.27 & 3.88 & & & 1.58 & 4.45 & 4.82 \\
\hline $\mathrm{TiO}_{2}$ & 0.08 & 0.31 & & & 0.13 & 0.62 & & & 0.57 & 0.11 & 0.11 \\
\hline $\mathrm{P}_{2} \mathrm{O}_{5}$ & 0.01 & 0.08 & & & 0.04 & 0.19 & & & 0.27 & 0.03 & 0.02 \\
\hline LOI & 0.47 & 0.46 & & & 0.40 & 0.64 & & & 2.03 & 0.43 & 0.49 \\
\hline Total & 99.1 & 99.0 & & & 99.2 & 98.7 & & & 98.3 & 99.1 & 98.6 \\
\hline $\begin{array}{l}\mathrm{Al} /(\mathrm{Ca}+ \\
\mathrm{Na}+\mathrm{K})\end{array}$ & 1.07 & 1.08 & & & 1.05 & 1.06 & & & 1.11 & 1.04 & 1.10 \\
\hline $\mathrm{Al} /(\mathrm{Na}+\mathrm{K})$ & 1.15 & 1.17 & & & 1.13 & 1.26 & & & 1.57 & 1.13 & 1.18 \\
\hline Q & 36.73 & 34.72 & & & 37.09 & 27.35 & & & 17.75 & 37.03 & 36.34 \\
\hline Or & 27.61 & 30.94 & & & 25.54 & 23.39 & & & 9.70 & 26.66 & 29.03 \\
\hline $\mathrm{Ab}$ & 31.74 & 26.79 & & & 33.24 & 33.93 & & & 49.85 & 32.08 & 30.10 \\
\hline An & 2.10 & 2.04 & & & 1.95 & 4.30 & & & 11.25 & 2.27 & 2.14 \\
\hline Mg-Hy & 0.20 & 1.54 & & & 0.28 & 3.10 & & & 3.36 & 0.40 & 0.28 \\
\hline Fe-Hy & & & & & & 1.69 & & & 0.61 & & \\
\hline Ap & 0.02 & 0.19 & & & 0.09 & 0.45 & & & 0.65 & 0.07 & 0.05 \\
\hline $\mathrm{Ilm}$ & 0.02 & 0.60 & & & 0.11 & 1.20 & & & 1.12 & 0.04 & 0.04 \\
\hline $\mathrm{Ru}$ & 0.07 & & & & 0.07 & & & & & 0.09 & 0.09 \\
\hline Cor & 0.88 & 1.11 & & & 0.75 & 1.27 & & & 2.45 & 0.61 & 1.21 \\
\hline Hem & 1.67 & 1.47 & & & 1.71 & & & & & 1.69 & 1.69 \\
\hline Mag & & 0.57 & & & & 3.08 & & & 3.03 & & \\
\hline DI & 98.18 & 94.49 & & & 97.82 & 88.97 & & & 88.55 & 98.04 & 97.61 \\
\hline $\begin{array}{l}\text { Trace elements } \\
\text { (in ppm, by }\end{array}$ & & & (ICP-MS) & Diff $(\%$ & & & (ICP-MS) & Diff $(\%$ & & & \\
\hline $\mathrm{Nb}$ & 11.5 & 16.9 & 14.70 & -15 & 13.8 & 24.4 & 21.47 & -14 & 12.4 & 20.8 & 19.2 \\
\hline $\mathrm{Zr}$ & 79 & 150 & 135.07 & -11 & 59 & 289 & 323.66 & 11 & 210 & 84 & 98 \\
\hline $\mathrm{Y}$ & 4 & 12 & 12.09 & 1 & 7 & 24 & 21.67 & -11 & 21 & 14 & 20 \\
\hline $\mathrm{Sr}$ & 35 & 78 & 74.44 & -5 & 31 & 121 & 115.52 & -5 & 413 & 33 & 28 \\
\hline $\mathrm{Rb}$ & 119 & 143 & 153.44 & 7 & 140 & 167 & 175.65 & 5 & 125 & 142 & 154 \\
\hline $\mathrm{Co}$ & $<1$ & 2 & 2.21 & 10 & 1 & 5 & 4.56 & -10 & 8 & $<1$ & 1 \\
\hline V & 4 & 17 & 12.41 & -37 & 7 & 36 & 28.56 & -26 & 67 & 8 & 7 \\
\hline $\mathrm{Ni}$ & 4 & 1 & 2.61 & 62 & 2 & 4 & 3.33 & -20 & 3 & 2 & 2 \\
\hline $\mathrm{Cr}$ & 9 & 3 & 0.28 & -953 & 6 & 7 & 2.69 & -160 & 5 & 3 & 4 \\
\hline $\mathrm{Ba}$ & 416 & 1258 & 1109.56 & -13 & 294 & 939 & 871.25 & -8 & 501 & 174 & 131 \\
\hline $\mathrm{Ga}$ & 15 & 15 & 16.23 & 8 & 13 & 19 & 20.75 & 8 & 21 & 14 & 14 \\
\hline $\mathrm{Cu}$ & 3 & 2 & 2.39 & 16 & $<1$ & 2 & 3.37 & 41 & 201 & 1 & 5 \\
\hline $\mathrm{Zn}$ & 10 & 56 & 60.21 & 7 & 16 & 96 & 105.95 & 9 & 31 & 20 & 27 \\
\hline Th & 6 & 12 & 17.19 & 30 & 9 & 23 & 28.86 & 20 & 4 & 10 & 14 \\
\hline $\mathrm{U}$ & 2 & 2 & 1.95 & -3 & 3 & 2 & 2.03 & 2 & 3 & 5 & 11 \\
\hline $\mathrm{Pb}$ & 17 & 21 & 23.55 & 11 & 23 & 17 & 17.77 & 4 & 11 & 22 & 22 \\
\hline $\mathrm{La}$ & 9 & 30 & & & 15 & 51 & & & 23 & 14 & 15 \\
\hline $\mathrm{Ce}$ & 21 & 63 & & & 37 & 98 & & & 49 & 33 & 34 \\
\hline $\mathrm{Nd}$ & 5 & 25 & & & 13 & 40 & & & 23 & 9 & 13 \\
\hline
\end{tabular}


Table 2 (continued)

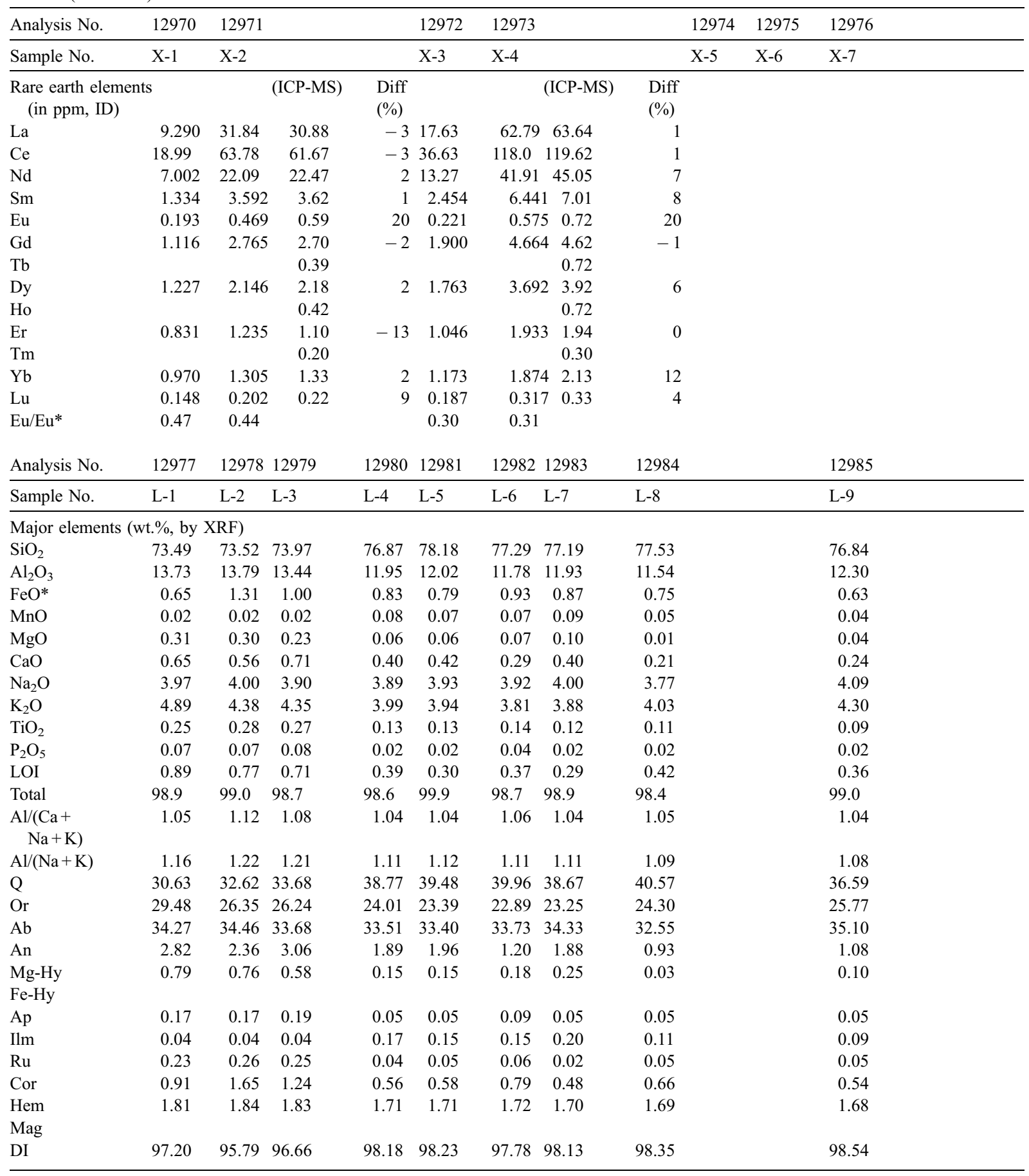


Table 2 (continued)

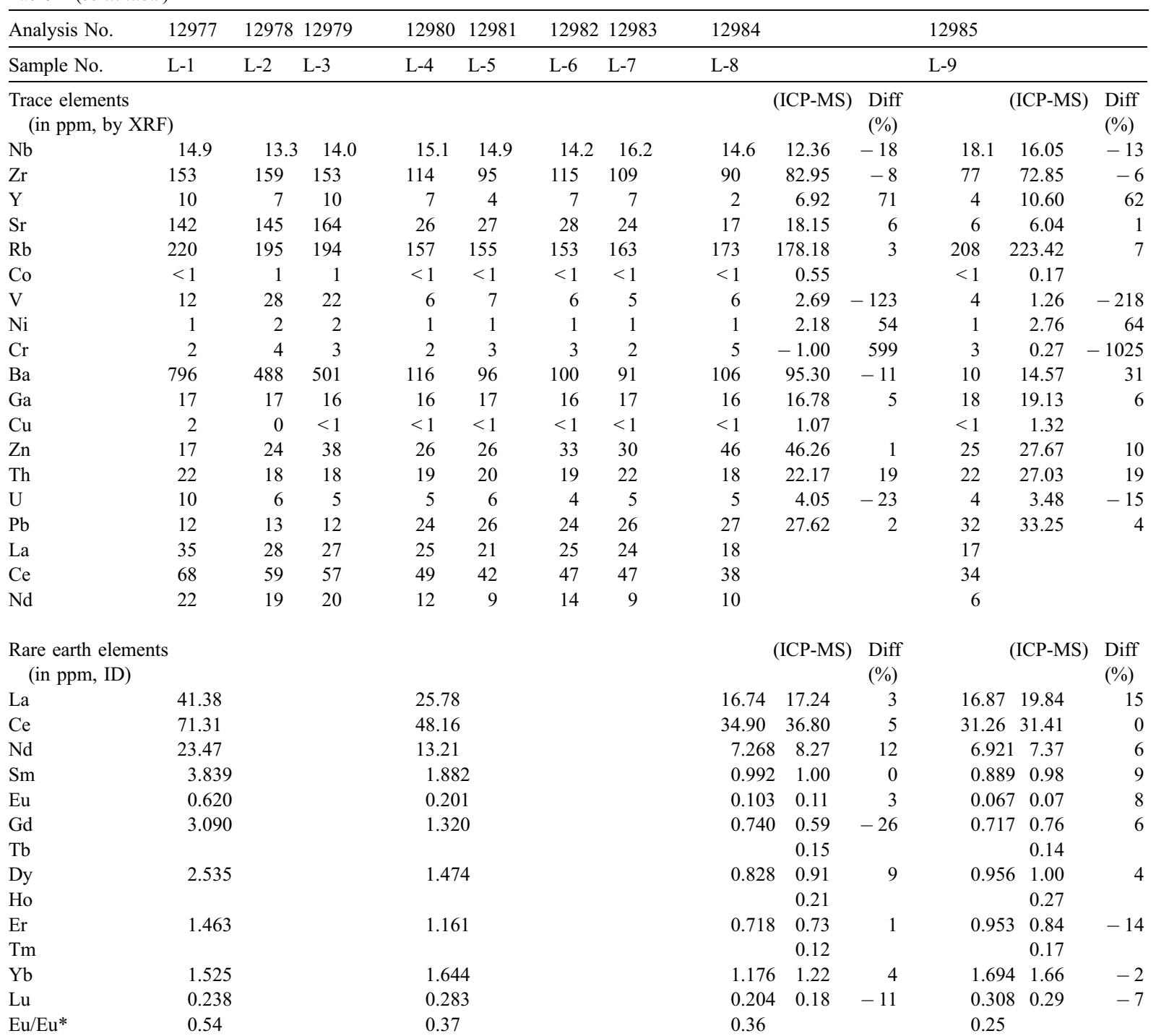

\begin{tabular}{|c|c|c|c|c|c|c|c|c|c|}
\hline Analysis No. & 12986 & 129871 & 12988 & 12989 & 12990 & 12991 & 12992 & 12993 & 12974 \\
\hline Sample No. & YE-1 & YE-2 Y & YE-3 & YE-4 & YE-5 & YE-6 & YE-7 & YE-8 & YE-9 \\
\hline \multicolumn{10}{|c|}{ Major elements (wt.\%, by XRF) } \\
\hline $\mathrm{SiO}_{2}$ & 77.02 & 75.97 & 73.93 & 76.10 & 71.33 & 77.19 & 76.51 & 75.88 & 73.59 \\
\hline $\mathrm{Al}_{2} \mathrm{O}_{3}$ & 11.49 & 12.35 & 13.42 & 12.60 & 14.62 & 12.18 & 12.09 & 12.40 & 13.51 \\
\hline $\mathrm{FeO}^{*}$ & 1.29 & 0.91 & 1.11 & 0.99 & 1.46 & 0.94 & 0.93 & 0.86 & 1.30 \\
\hline $\mathrm{MnO}$ & 0.04 & 0.02 & 0.03 & 0.01 & 0.05 & 0.02 & 0.02 & 0.02 & 0.04 \\
\hline $\mathrm{MgO}$ & 0.04 & 0.10 & 0.31 & 0.21 & 0.28 & 0.09 & 0.00 & 0.05 & 0.22 \\
\hline $\mathrm{CaO}$ & 0.11 & 0.27 & 0.41 & 0.25 & 0.88 & 0.26 & 0.28 & 0.25 & 0.54 \\
\hline $\mathrm{Na}_{2} \mathrm{O}$ & 3.59 & 3.74 & 4.12 & 3.65 & 4.57 & 4.00 & 3.94 & 3.73 & 3.64 \\
\hline $\mathrm{K}_{2} \mathrm{O}$ & 4.44 & 4.65 & 4.91 & 4.76 & 4.82 & 4.31 & 4.44 & 4.72 & 5.15 \\
\hline $\mathrm{TiO}_{2}$ & 0.15 & 0.14 & 0.22 & 0.15 & 0.26 & 0.08 & 0.08 & 0.16 & 0.20 \\
\hline
\end{tabular}


Table 2 (continued)

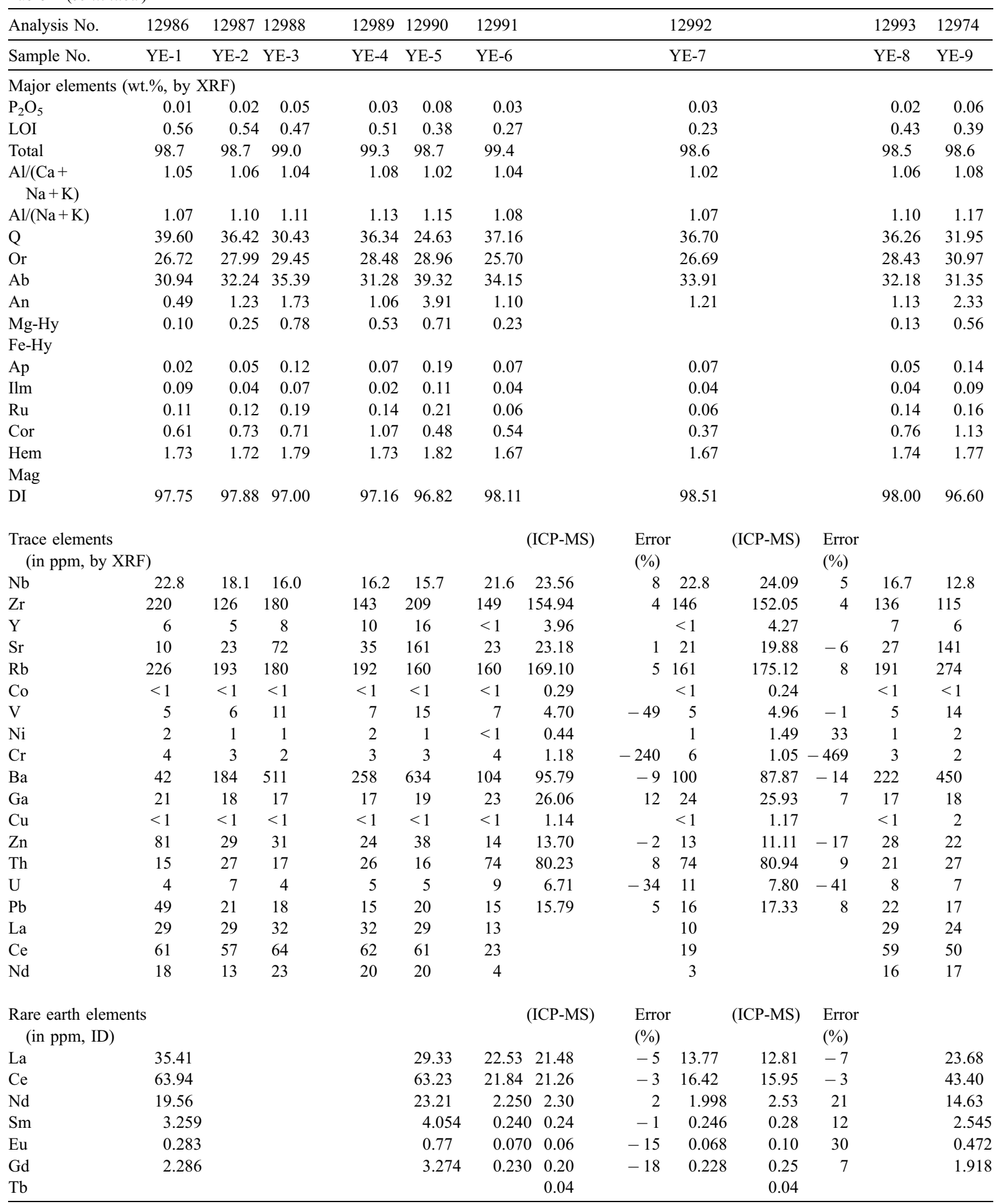


Table 2 (continued)

\begin{tabular}{|c|c|c|c|c|c|c|c|c|c|c|c|c|c|}
\hline Analysis No. & 12986 & 12987 & 12988 & 12989 & 12990 & 12991 & & & 12992 & & & 12993 & 12974 \\
\hline Sample No. & YE-1 & YE-2 & YE-3 & YE-4 & YE-5 & YE-6 & & & YE-7 & & & YE-8 & YE-9 \\
\hline \multicolumn{2}{|c|}{$\begin{array}{l}\text { Rare earth elements } \\
\quad \text { (in ppm, ID) }\end{array}$} & & & & & & CP-MS) & $\begin{array}{l}\text { Errol } \\
(\%)\end{array}$ & & (ICP-MS) & $\begin{array}{l}\text { Error } \\
(\%)\end{array}$ & & \\
\hline Dy & 1.942 & & & & 2.884 & 0.260 & 0.29 & 11 & 0.296 & 0.29 & -1 & & 1.612 \\
\hline Но & & & & & & & 0.08 & & & 0.09 & & & \\
\hline Er & 1.181 & & & & 1.716 & 0.360 & 0.32 & -13 & 0.407 & 0.32 & -27 & & 1.010 \\
\hline $\mathrm{Tm}$ & & & & & & & 0.08 & & & 0.11 & & & \\
\hline $\mathrm{Yb}$ & 1.471 & & & & 1.816 & 1.000 & 0.95 & -5 & 1.102 & 1.08 & -2 & & 1.288 \\
\hline $\mathrm{Lu}$ & 0.236 & & & & & 0.230 & 0.21 & -9 & 0.253 & 0.24 & -3 & & 0.228 \\
\hline $\mathrm{Eu} / \mathrm{Eu}^{*}$ & 0.30 & & & & 0.63 & 0.880 & & & 0.87 & & & & 0.63 \\
\hline
\end{tabular}

Total iron as $\mathrm{FeO}^{*}$.

$\mathrm{Al} /(\mathrm{Ca}+\mathrm{Na}+\mathrm{K})$ and $\mathrm{Al} /(\mathrm{Na}+\mathrm{K})$ are molar ratios.

$\mathrm{DI}=$ Differentiation Index.

MAT-262 mass spectrometer. ${ }^{87} \mathrm{Sr} /{ }^{86} \mathrm{Sr}$ ratios were normalized against the value of ${ }^{86} \mathrm{Sr}{ }^{88} \mathrm{Sr}=0.1194$. Seven replicate analyses on NBS-987 $\mathrm{Sr}$ standard yielded ${ }^{87} \mathrm{Sr} /{ }^{86} \mathrm{Sr}=0.710259 \pm 6$.

$\mathrm{Rb}-\mathrm{Sr}$ isochron ages were calculated using the regression program of ISOPLOT (Ludwig, 1999). Input errors are $2 \%$ for ${ }^{87} \mathrm{Rb} /{ }^{86} \mathrm{Sr}$ and $0.005 \%$ for ${ }^{87} \mathrm{Sr} /{ }^{86} \mathrm{Sr}$. Unless specified, the errors quoted in age computation represent \pm 2 standard deviations $(2 \sigma)$.

\subsection{Ar-Ar analyses}

Four K-feldspar separates were prepared for ${ }^{40} \mathrm{Ar} /{ }^{39} \mathrm{Ar}$ analyses. Pure mineral separates were obtained by magnetic separation followed by heavy liquid treatment and final handpicking under the microscope to remove all visible impurities. Aliquots of feldspar separates were wrapped in aluminum foil packets and stacked in an aluminum canister with irradiation standard LP-6 biotite which has a $\mathrm{K}-\mathrm{Ar}$ age of $127.7 \pm 1.4 \mathrm{Ma}$ (Odin et al., 1982). The samples were irradiated in the VT-C position of the THOR Reactor at Tsing-Hua University (Taiwan) for $8 \mathrm{~h}$, receiving a neutron flux of $1.566 \times 10^{13} \mathrm{n} / \mathrm{cm} / \mathrm{s}$. The mean $J$ values were 0.0010427 and 0.0010265 for two irradiation procedures in June and December, 1996. The variation in flux across the samples is less than $0.8 \%$. After irradiation, samples were removed from the Al foil packets, and loaded into fused quartz boats which were previously degassed in vacuo at $1200{ }^{\circ} \mathrm{C}$ for $3 \mathrm{~h}$. During the ${ }^{40} \mathrm{Ar} /{ }^{39} \mathrm{Ar}$ experiments, all samples were heated stepwise with a Lindberg resistance furnace following a $30 \mathrm{~min} /$ step schedule from 500 to $1200{ }^{\circ} \mathrm{C}$. The released gas was purified with a $\mathrm{Ti}$ sponge and $\mathrm{Zr}-\mathrm{Al}$ getters and measured with a Varian-MAT GD150 mass spectrometer run in a static mode at the National Taiwan University. All Ar isotope analyses were corrected for system blanks, neutron-induced interferences, radioactive decay and mass discrimination. The quoted uncertainties (at $1 \sigma$ ) include systematic errors in $J$ value and age of the flux monitors, but exclude the errors in the interference corrections. A more detailed description of the analytical procedures and data reduction was given by Lo and Lee (1994). The results of ${ }^{40} \mathrm{Ar} /{ }^{39} \mathrm{Ar}$ analyses are shown as age spectrum and isotope correlation plots. Plateau ages were calculated from the sum total of the gas compositions for the successive temperature steps with ages agreeing within $2 \sigma$. Data regression for the isotope correlation diagrams was done using the cubic leastsquares fitting scheme of York (1969).

\section{Major and trace element abundances}

The results of chemical analyses for the three plutons are listed in Table 2 . The granites are silicarich, with $\mathrm{SiO}_{2}$ ranging from $69 \%(\mathrm{X}-4)$ to $78 \%$ (L$5)$. They have high contents of alkalis, with $\mathrm{K}_{2} \mathrm{O}=3.8-5.2 \%$ and $\mathrm{Na}_{2} \mathrm{O}=3.1-4.6 \%$ (except for enclave $\mathrm{X}-5$ ), but low abundances in $\mathrm{Fe}_{2} \mathrm{O}_{3}$ (total $\mathrm{Fe}$ ) (0.6-4.4\%), $\mathrm{MnO}(0.0-0.3 \%), \mathrm{MgO}(0.0-1.2 \%)$, $\mathrm{CaO}(0.1-1.1 \%), \mathrm{TiO}_{2}(0.1-0.6 \%)$ and $\mathrm{P}_{2} \mathrm{O}_{5}(0.0-$ $0.2 \%) . \mathrm{Al}_{2} \mathrm{O}_{3}$ ranges from $11.5 \%$ to $14.6 \%$. The 


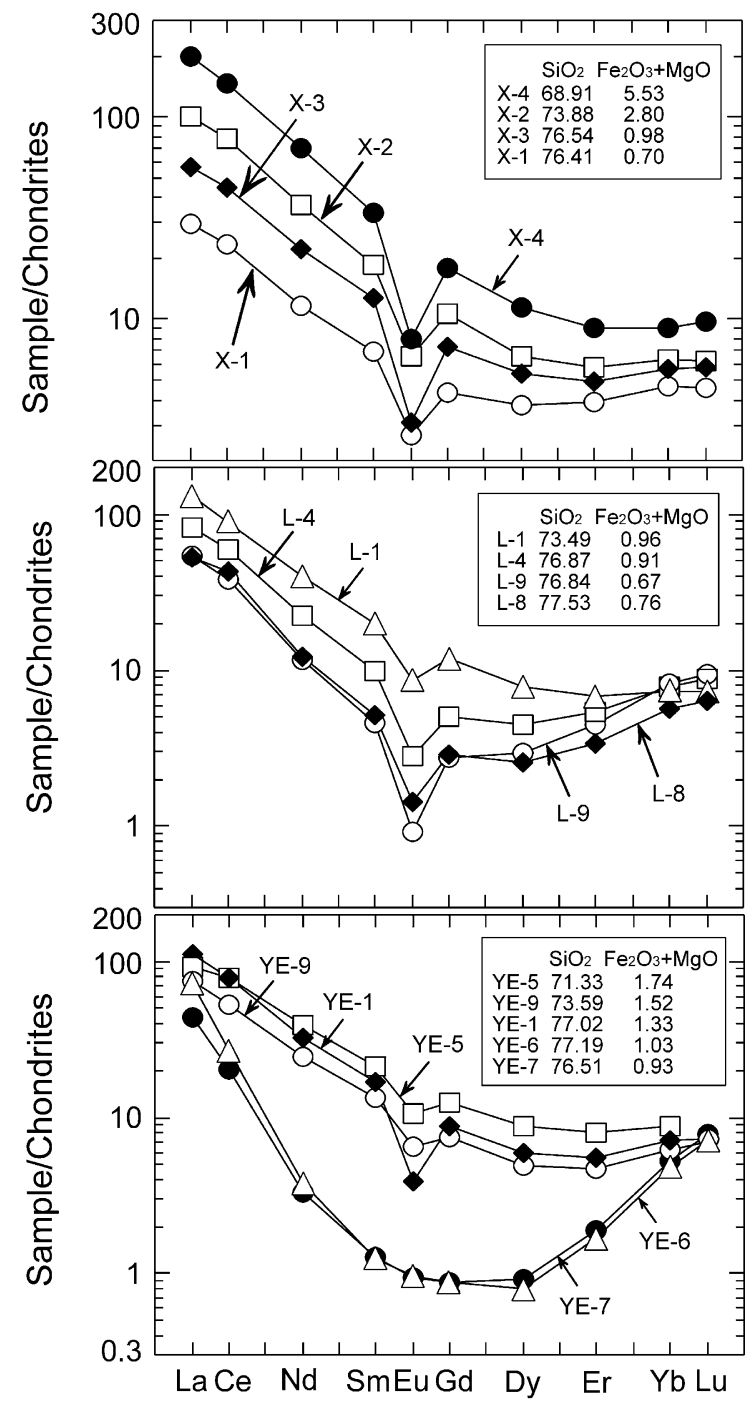

Fig. 3. Chondrite-normalized REE patterns for the granites from NE China. Note that the REE abundances are inversely proportional to $\mathrm{SiO}_{2}$ contents. The distinctive concave patterns of YE-6 and YE-7 may be related to the fractionation of apatite and allanite.

Shand's index $\mathrm{A} / \mathrm{CNK}\left(\mathrm{Al}_{2} \mathrm{O}_{3} /\left[\mathrm{CaO}+\mathrm{K}_{2} \mathrm{O}+\mathrm{Na}_{2} \mathrm{O}\right]\right.$, in mole) indicates that these rocks are peraluminous and expressed by the presence of normative corundum (Table 2). All the samples are silica-oversaturated with $27-41 \%$ of normative quartz (except enclave X-5).

Chondrite-normalized REE patterns (Fig. 3) invariably show light REE enrichment and signifi- cant negative $\mathrm{Eu}$ anomalies. In each pluton, total REE abundances decrease with increasing $\mathrm{SiO}_{2}$ (DI, Fig. 3). However, samples YE-6 and YE-7 are distinctive for their low and concave REE patterns with no $\mathrm{Eu}$ anomalies. The generation of this pattern is not precisely understood, but it could be modeled by fractionation of apatite, allanite, titanite or monazite (see later discussion). In the primitive mantle normalized variation diagrams (Fig. 4), all the granitic rocks show characteristic negative anomalies in $\mathrm{Ba}, \mathrm{Nb}, \mathrm{Sr}, \mathrm{P}, \mathrm{Eu}$ and $\mathrm{Ti}$, and a positive anomaly for $\mathrm{Pb}$.

\section{Geochronology}

The results of zircon SHRIMP analyses are listed in Table 3, $\mathrm{Rb}-\mathrm{Sr}$ isotopic data for whole-rock (WR) and mineral samples are given in Table 4 and $\mathrm{Ar}$ isotopic analyses are presented in Table 5. The age results for the three plutons are discussed below.

\subsection{Xinhuatun pluton}

SHRIMP $\mathrm{U}-\mathrm{Pb}$ analyses on 10 zircon grains from sample X-4 are shown in Fig. 5a. Eight grains give a tight range of ${ }^{206} \mathrm{~Pb} /{ }^{238} \mathrm{U}$ ratios, yielding an age of $184 \pm 4 \mathrm{Ma}$. These define a single population of weak to moderately zoned crystals with welldeveloped crystal faces, typical of magmatic zircons. The slightly older and younger grains have a similar morphology and are not readily distinguishable from the main population. The older grain is most likely inherited from a slightly older source, whereas the younger grain is reversely discordant and the $\mathrm{Pb}$ isotopic system shows post-crystallization disturbance (Table 3). We therefore take the age of $184 \pm 4 \mathrm{Ma}$ to represent the time of granitic intrusion. Whole-rock $\mathrm{Rb}-\mathrm{Sr}$ data of this pluton define an isochron of $173 \pm 3 \mathrm{Ma}$ with $\left({ }^{87} \mathrm{Sr} /{ }^{86} \mathrm{Sr}\right)_{\mathrm{i}}$ (initial $\mathrm{Sr}$ isotopic ratio) $=0.7045 \pm 1$ (Fig. 6a). If the enclave data (X-5) are excluded, the calculated age remains the same. The $\mathrm{Rb}-\mathrm{Sr}$ age is slightly younger than the zircon age. We also analyzed biotites and feldspars from samples X-2 and X-4 in order to constrain the minimum age of intrusion and estimate the rate of magma cooling. The results yielded two 


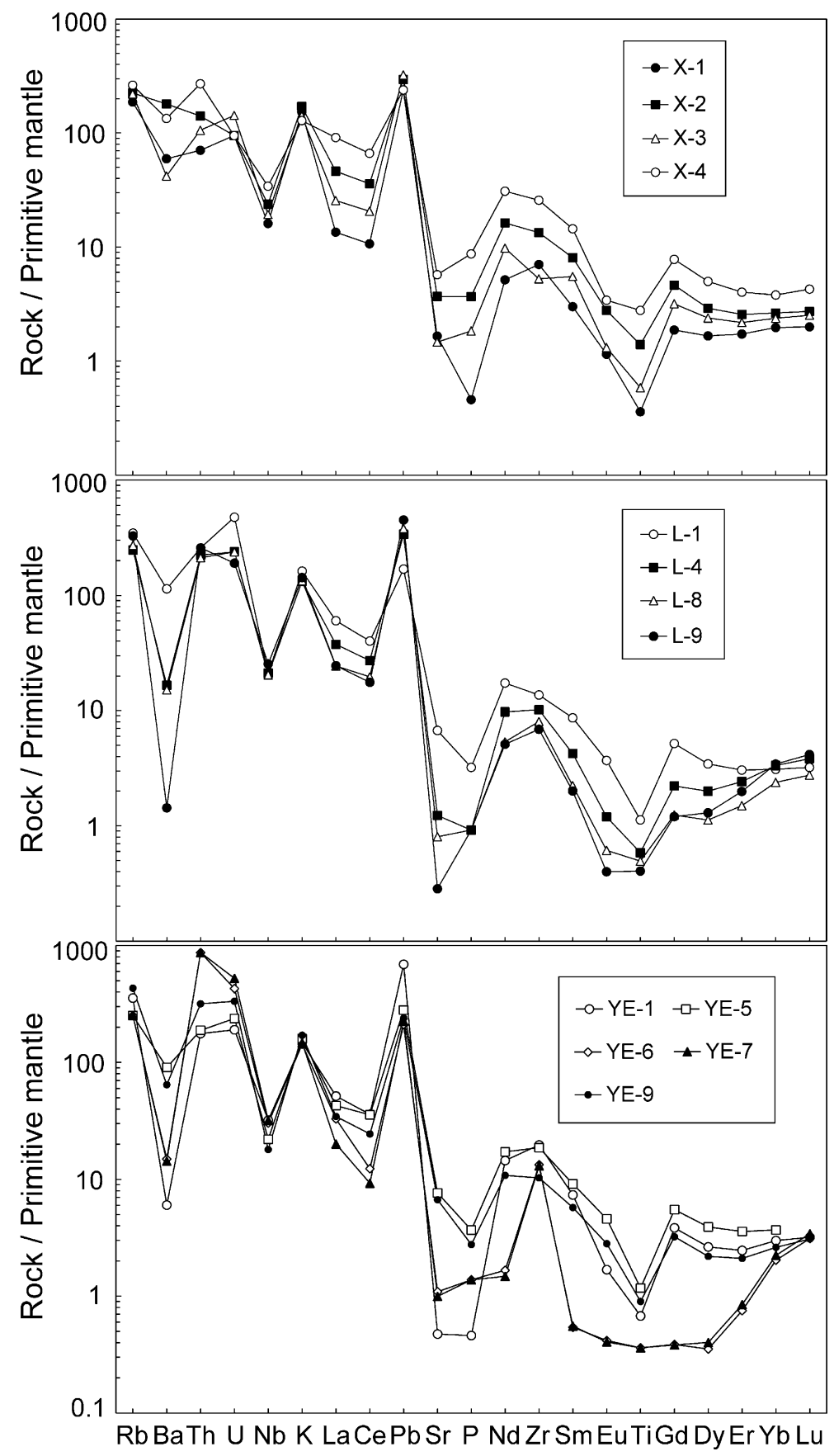

Fig. 4. Primitive-mantle (PM) normalized spidergrams for the granites from NE China. Elements are arranged in the order of decreasing incompatibility from left to right. The primitive mantle values (in ppm) are from Sun and McDonough (1989). 
biotite ages (Bi-WR and $\mathrm{Bi}-\mathrm{Kf}$ ) of $165 \pm 4$ and $167 \pm 4$ Ma for X-2 (Fig. 6b) and $160 \pm 3$ and $162 \pm 4 \mathrm{Ma}$ for X-4 (Fig. 6c). These biotite ages correspond to the time when biotite was cooled to its blocking temperature of about $300-250{ }^{\circ} \mathrm{C}$ (Jager et al., 1967). The low initial ${ }^{87} \mathrm{Sr} /{ }^{86} \mathrm{Sr}$ ratios of 0.7045 indicate that the protoliths of the granites were dominated by depleted mantle-derived materials, such as basaltic rocks or granitoids with short crustal residence time. Assuming the magmatic temperature was $750{ }^{\circ} \mathrm{C}$ (Chappell et al., 2000), the rate of cooling calculated from the zircon $\mathrm{U}-\mathrm{Pb}$, WR $\mathrm{Rb}-\mathrm{Sr}$ isochron and biotite ages yields $\approx 25{ }^{\circ} \mathrm{C} /$ Ma.

\subsection{Lamashan pluton}

Nine WR $\mathrm{Rb}-\mathrm{Sr}$ isotopic analyses yielded an excellent isochron age of $154 \pm 3 \mathrm{Ma}$ with $\left({ }^{87} \mathrm{Sr} /{ }^{86} \mathrm{Sr}\right)_{\mathrm{i}}=$ $0.7049 \pm 2$ (Fig. 7), which is interpreted as the emplacement age of the Lamashan pluton. Zircon separation was attempted, but no satisfactory SHRIMP analysis was obtained on the few available grains. Because the Lamashan granites are poor in biotite, this phase could not be separated for isotopic analysis. On the other hand, two K-feldspar separates, from samples L-1 and L-4, were analyzed for $\mathrm{Ar}$ isotopes. As shown in Fig. 8, except for some discordance in the low-temperature steps of L-1 K-feldspar,

Table 3

SHRIMP $\mathrm{U}-\mathrm{Pb}-\mathrm{Th}$ analytical data of zircons for the granites in NE China

\begin{tabular}{|c|c|c|c|c|c|c|c|c|c|c|c|c|c|c|c|c|c|}
\hline \multirow[t]{2}{*}{ Spot } & \multirow{2}{*}{$\begin{array}{l}\mathrm{U} \\
(\mathrm{ppm})\end{array}$} & \multirow{2}{*}{$\begin{array}{l}\text { Th } \\
(\mathrm{ppm})\end{array}$} & \multirow[t]{2}{*}{$\mathrm{Th} / \mathrm{U}$} & \multirow{2}{*}{$\begin{array}{l}\mathrm{Pb} \\
(\mathrm{ppm})\end{array}$} & \multicolumn{7}{|c|}{ Isotopic ratios } & \multicolumn{6}{|c|}{ Age (Ma) } \\
\hline & & & & & $\begin{array}{l}{ }^{204} \mathrm{~Pb} / \\
{ }^{206} \mathrm{~Pb}\end{array}$ & $\begin{array}{l}{ }^{207} \mathrm{~Pb}^{\mathrm{a}} / \\
{ }^{206} \mathrm{~Pb}^{\mathrm{a}}\end{array}$ & $1 \sigma$ & $\begin{array}{l}{ }^{206} \mathrm{~Pb}^{\mathrm{a}} / \\
{ }^{238} \mathrm{U}\end{array}$ & $1 \sigma$ & $\begin{array}{l}{ }^{207} \mathrm{~Pb}^{\mathrm{a}} / \\
{ }^{235} \mathrm{U}\end{array}$ & $1 \sigma$ & $\begin{array}{l}{ }^{206} \mathrm{~Pb}^{\mathrm{a} /} \\
{ }^{238} \mathrm{U}\end{array}$ & $1 \sigma$ & $\begin{array}{l}{ }^{207} \mathrm{~Pb}^{\mathrm{a}} / \\
{ }^{235} \mathrm{U}\end{array}$ & $1 \sigma$ & $\begin{array}{l}{ }^{207} \mathrm{~Pb}^{\mathrm{a}} / \\
{ }^{206} \mathrm{~Pb}^{\mathrm{a}}\end{array}$ & $1 \sigma$ \\
\hline \multicolumn{18}{|c|}{ Xinhuatun pluton $(X-4)$} \\
\hline$x 4-1$ & 574 & 481 & 0.84 & 18 & 0 & 0.04968 & 124 & 0.0281 & 7 & 0.193 & 7 & 179 & 4 & 179 & 6 & 180 & 58 \\
\hline$x 4-2$ & 760 & 393 & 0.52 & 23 & 0 & 0.05134 & 100 & 0.0293 & 7 & 0.207 & 7 & 186 & 4 & 191 & 6 & 256 & 45 \\
\hline$x 4-3$ & 408 & 102 & 0.25 & 12 & 0.00034 & 0.05348 & 178 & 0.0299 & 7 & 0.221 & 9 & 190 & 4 & 202 & 8 & 349 & 75 \\
\hline$x 4-4$ & 862 & 840 & 0.97 & 36 & 0.00299 & 0.05373 & 306 & 0.0298 & 7 & 0.221 & 14 & 189 & 4 & 203 & 12 & 360 & 129 \\
\hline$x 4-5$ & 185 & 69 & 0.37 & 5 & 0.00017 & 0.04801 & 288 & 0.0289 & 7 & 0.191 & 13 & 184 & 5 & 178 & 11 & 100 & 135 \\
\hline$x 4-6$ & 318 & 112 & 0.35 & 9 & 0 & 0.05098 & 212 & 0.0292 & 7 & 0.205 & 10 & 185 & 4 & 189 & 9 & 240 & 96 \\
\hline$x 4-7$ & 511 & 345 & 0.67 & 18 & 0.00016 & 0.04966 & 189 & 0.0328 & 8 & 0.225 & 10 & 208 & 5 & 206 & 9 & 179 & 88 \\
\hline$x 4-8$ & 522 & 479 & 0.92 & 16 & 0.00020 & 0.04731 & 136 & 0.0266 & 6 & 0.173 & 7 & 169 & 4 & 162 & 6 & 68 & 64 \\
\hline$x 4-9$ & 465 & 340 & 0.73 & 15 & 0.00009 & 0.05027 & 158 & 0.0288 & 7 & 0.200 & 8 & 183 & 4 & 185 & 7 & 208 & 73 \\
\hline $\mathrm{x} 4-10$ & 588 & 160 & 0.27 & 16 & 0.00017 & 0.05036 & 154 & 0.0279 & 6 & 0.193 & 8 & 177 & 4 & 180 & 7 & 212 & 71 \\
\hline \multicolumn{18}{|c|}{ Yiershi pluton (YE-1) } \\
\hline YE1-2 & 1154 & 1386 & 1.20 & 26 & 0.00023 & 0.04775 & 214 & 0.0190 & 4 & 0.125 & 7 & 121 & 3 & 120 & 6 & 88 & 101 \\
\hline YE1-3 & 525 & 377 & 0.72 & 12 & 0 & 0.05110 & 233 & 0.0216 & 4 & 0.152 & 8 & 138 & 3 & 144 & 7 & 245 & 105 \\
\hline YE1-4 & 534 & 461 & 0.86 & 13 & 0.00012 & 0.05222 & 192 & 0.0220 & 5 & 0.159 & 7 & 140 & 3 & 149 & 6 & 295 & 84 \\
\hline YE1-4a & 436 & 389 & 0.89 & 12 & 0.00023 & 0.03795 & 388 & 0.0226 & 5 & 0.118 & 13 & 144 & 3 & 113 & 11 & 0 & 121 \\
\hline YE1-5 & 476 & 351 & 0.74 & 11 & 0.00065 & 0.05185 & 238 & 0.0216 & 4 & 0.154 & 8 & 138 & 3 & 146 & 7 & 279 & 105 \\
\hline YE1-6 & 773 & 700 & 0.91 & 19 & 0 & 0.04884 & 206 & 0.0215 & 4 & 0.145 & 7 & 137 & 3 & 137 & 6 & 140 & 95 \\
\hline YE1-7 & 4125 & 5493 & 1.33 & 114 & 0.00002 & 0.04821 & 410 & 0.0220 & 4 & 0.146 & 3 & 140 & 2 & 139 & 3 & 110 & 20 \\
\hline YE1-9 & 428 & 433 & 1.01 & 9 & 0.00012 & 0.05119 & 330 & 0.0176 & 5 & 0.124 & 9 & 112 & 3 & 119 & 8 & 249 & 148 \\
\hline YE1-10 & 533 & 391 & 0.73 & 13 & 0.00003 & 0.05032 & 116 & 0.0214 & 4 & 0.149 & 5 & 137 & 3 & 141 & 4 & 210 & 53 \\
\hline YE1-11 & 441 & 426 & 0.96 & 11 & 0 & 0.04966 & 129 & 0.0213 & 4 & 0.146 & 5 & 136 & 3 & 139 & 4 & 179 & 61 \\
\hline YE1-12 & 4918 & 6032 & 1.23 & 117 & 0.00002 & 0.04891 & 92 & 0.0195 & 4 & 0.132 & 4 & 125 & 2 & 126 & 3 & 144 & 44 \\
\hline YE1-13 & 4852 & 5779 & 1.19 & 113 & 0.00011 & 0.04860 & 93 & 0.0193 & 4 & 0.129 & 4 & 123 & 2 & 123 & 3 & 129 & 44 \\
\hline YE1-14 & 4625 & 5675 & 1.23 & 120 & 0.00002 & 0.04868 & 43 & 0.0210 & 4 & 0.141 & 3 & 134 & 2 & 134 & 3 & 133 & 20 \\
\hline YE1-15 & 4287 & 5382 & 1.26 & 112 & 0.00001 & 0.04826 & 41 & 0.0211 & 4 & 0.140 & 3 & 134 & 2 & 133 & 3 & 112 & 19 \\
\hline YE1-16 & 399 & 367 & 0.92 & 10 & 0.00003 & 0.04912 & 292 & 0.0210 & 4 & 0.142 & 9 & 134 & 3 & 135 & 8 & 154 & 131 \\
\hline YE1-17 & 453 & 331 & 0.73 & 10 & 0.00019 & 0.04693 & 124 & 0.0211 & 4 & 0.136 & 5 & 134 & 3 & 130 & 4 & 51 & 57 \\
\hline
\end{tabular}

${ }^{\text {a }}{ }^{208} \mathrm{~Pb}$ corrected. 
Table 4

$\mathrm{Rb}$-Sr-isotopic compositions of granites in NE China

\begin{tabular}{|c|c|c|c|c|c|c|c|}
\hline Analysis No. & Sample No. & $\mathrm{Rb}(\mathrm{ppm})$ & $\mathrm{Sr}(\mathrm{ppm})$ & ${ }^{87} \mathrm{Rb} /{ }^{86} \mathrm{Sr}$ & ${ }^{87} \mathrm{Sr} /{ }^{86} \mathrm{Sr}$ & $2 \sigma_{\mathrm{m}}$ & $\left({ }^{87} \mathrm{Sr} /{ }^{86} \mathrm{Sr}\right)_{\mathrm{i}}$ \\
\hline \multicolumn{8}{|l|}{ Xinhuatun } \\
\hline 12970 & $\mathrm{X}-1$ & 119 & 35 & 9.86 & 0.728612 & 6 & 0.7055 \\
\hline \multirow[t]{3}{*}{12971} & $X-2$ & 143 & 98 & 5.31 & 0.717756 & 6 & 0.7053 \\
\hline & $\mathrm{Bi}$ & 409.6 & 14.96 & 80.66 & 0.894020 & 6 & \\
\hline & $\mathrm{Kf}$ & 203.6 & 106.1 & 5.56 & 0.715879 & 6 & \\
\hline 12972 & $X-3$ & 140 & 31 & 13.10 & 0.736430 & 6 & 0.7057 \\
\hline \multirow[t]{4}{*}{12973} & $\mathrm{X}-4$ & 167 & 121 & 4.00 & 0.714201 & 7 & 0.7048 \\
\hline & $\mathrm{Bi}$ & 592.8 & 18.93 & 92.44 & 0.915324 & 8 & \\
\hline & $\mathrm{Kf}$ & 237.3 & 120.1 & 5.72 & 0.715362 & 8 & \\
\hline & $\mathrm{Pl}$ & 19.1 & 281.4 & 0.20 & 0.704936 & 6 & \\
\hline 12974 & $X-5$ & 125 & 413 & 0.88 & 0.706616 & 5 & 0.7046 \\
\hline 12975 & $X-6$ & 142 & 33 & 12.48 & 0.734809 & 6 & 0.7055 \\
\hline 12976 & $X-7$ & 154 & 28 & 15.97 & 0.744306 & 7 & 0.7068 \\
\hline \multicolumn{8}{|l|}{ Lamashan } \\
\hline 12977 & L-1 & 206.5 & 135.9 & 4.40 & 0.714372 & 8 & 0.7047 \\
\hline 12978 & L-2 & 186.0 & 144.3 & 3.73 & 0.713009 & 7 & 0.7048 \\
\hline 12979 & L-3 & 186.5 & 154.5 & 3.49 & 0.712291 & 5 & 0.7047 \\
\hline 12980 & L-4 & 151.3 & 25.95 & 16.92 & 0.741003 & 9 & 0.7040 \\
\hline 12981 & L-5 & 146.7 & 27.41 & 15.53 & 0.739380 & 7 & 0.7054 \\
\hline 12982 & L-6 & 145.5 & 27.86 & 15.10 & 0.737437 & 5 & 0.7044 \\
\hline 12983 & L-7 & 156.3 & 23.97 & 18.93 & 0.745549 & 7 & 0.7041 \\
\hline 12984 & L-8 & 165.8 & 18.05 & 26.72 & 0.761829 & 5 & 0.7033 \\
\hline 12985 & L-9 & 198.4 & 6.42 & 91.07 & 0.898993 & 7 & 0.6996 \\
\hline \multicolumn{8}{|l|}{ Yiershi } \\
\hline 12986 & YE-1 & 211.2 & 9.83 & 62.91 & 0.833145 & 7 & 0.7026 \\
\hline 12987 & YE-2 & 182.8 & 22.51 & 23.60 & 0.754149 & 7 & 0.7052 \\
\hline \multirow[t]{2}{*}{12988} & YE-3 & 169.2 & 71.15 & 6.89 & 0.719483 & 7 & 0.7052 \\
\hline & $\mathrm{Bi}$ & 799.5 & 7.46 & 328.8 & 1.325615 & 8 & \\
\hline 12989 & YE-4 & 181.8 & 34.32 & 15.37 & 0.734849 & 7 & 0.7030 \\
\hline \multirow[t]{2}{*}{12990} & YE-5 & 149.0 & 159.4 & 2.70 & 0.710403 & 6 & 0.7048 \\
\hline & $\mathrm{Bi}$ & 861.0 & 7.05 & 378.2 & 1.479904 & 9 & \\
\hline 12991 & YE-6 & 153.2 & 22.81 & 19.50 & 0.743859 & 7 & 0.7034 \\
\hline 12992 & YE-7 & 152.4 & 21.41 & 20.67 & 0.747255 & 7 & 0.7044 \\
\hline 12993 & YE-8 & 179.0 & 25.63 & 20.28 & 0.746042 & 7 & 0.7040 \\
\hline 12974 & YE-9 & 258.0 & 137.7 & 5.43 & 0.715591 & 7 & 0.7043 \\
\hline
\end{tabular}

$\left({ }^{87} \mathrm{Sr} /{ }^{86} \mathrm{Sr}\right)_{\mathrm{i}}$ values are calculated using the whole-rock $\mathrm{Rb}-\mathrm{Sr}$ isochron ages.

both K-feldspar separates display flat age spectra with well-defined plateaus for $>75 \%$ of the ${ }^{39} \mathrm{Ar}_{\mathrm{K}}$ released. The gas compositions for the plateau steps provide plateau ages of $128.0 \pm 0.6(1 \sigma) \mathrm{Ma}$ for L-1 and $120.9 \pm 0.5 \mathrm{Ma}$ for L-4 (Fig. $8 \mathrm{a}$ and b). These plateau ages are consistent with the intercept ages obtained from the regression of data for the plateau steps in the isotope correlation diagrams $(126.6 \pm 2.8 \mathrm{Ma}$ for L-1 $\mathrm{K}$-feldspar and $121.5 \pm 1.3$ Ma for L-4 K-feldspar) (Fig. $8 \mathrm{c}$ and d). Nevertheless, these ${ }^{40} \mathrm{Ar} /{ }^{39} \mathrm{Ar}$ plateau ages (128-121 Ma) are significantly younger (by about
$30 \mathrm{Ma}$ ) than the $\mathrm{WR} \mathrm{Rb}-\mathrm{Sr}$ isochron age of $154 \mathrm{Ma}$. Considering the K-feldspar Ar blocking temperature of ca. $150{ }^{\circ} \mathrm{C}$ (McDougall and Harrison, 1988), the age data suggest that the average cooling rate was ca. 20 ${ }^{\circ} \mathrm{C} / \mathrm{Ma}$.

\subsection{Yiershi pluton}

The results of 16 SHRIMP analyses on 12 zircon grains from sample YE-1 are shown in Fig. 5b. The main population of 12 analyses gave a tightly con- 
Table 5

Results of ${ }^{40} \mathrm{Ar} /{ }^{\beta 9} \mathrm{Ar}$ incremental heating experiments for A-type granites from ECAOB

\begin{tabular}{|c|c|c|c|c|c|c|c|c|}
\hline$T\left({ }^{\circ} \mathrm{C}\right)$ & $\begin{array}{l}\text { Cum. } \\
{ }^{39} \mathrm{Ar}_{\mathrm{K}}\end{array}$ & $\begin{array}{l}\text { Atmos. } \\
(\%)\end{array}$ & ${ }^{36} \mathrm{Ar} /{ }^{39} \mathrm{Ar}$ & ${ }^{37} \mathrm{Ar} /{ }^{39} \mathrm{Ar}$ & ${ }^{38} \mathrm{Ar} /{ }^{39} \mathrm{Ar}$ & ${ }^{40} \mathrm{Ar} /{ }^{39} \mathrm{Ar}$ & ${ }^{40} \mathrm{Ar} /{ }^{36} \mathrm{Ar}$ & Date (Ma) \\
\hline \multicolumn{9}{|c|}{ YE-1 (K-feldspar) } \\
\hline 550 & 0.097 & 42.431 & $0.16843 \mathrm{E}+00$ & $0.41815 \mathrm{E}-05$ & $0.60615 \mathrm{E}-01$ & $0.11733 \mathrm{E}+03$ & $0.69660 \mathrm{E}+03$ & $122.2 \pm 0.9$ \\
\hline 600 & 0.132 & 8.953 & $0.22388 \mathrm{E}-01$ & $0.11459 \mathrm{E}-04$ & $0.16454 \mathrm{E}-01$ & $0.73920 \mathrm{E}+02$ & $0.33017 \mathrm{E}+04$ & $121.7 \pm 2.5$ \\
\hline 650 & 0.167 & 8.423 & $0.21185 \mathrm{E}-01$ & $0.39426 \mathrm{E}-03$ & $0.21976 \mathrm{E}-01$ & $0.74354 \mathrm{E}+02$ & $0.35098 \mathrm{E}+04$ & $123.1 \pm 1.6$ \\
\hline 700 & 0.198 & 10.937 & $0.27960 \mathrm{E}-01$ & $0.12862 \mathrm{E}-04$ & $0.23211 \mathrm{E}-01$ & $0.75572 \mathrm{E}+02$ & $0.27029 \mathrm{E}+04$ & $121.7 \pm 1.3$ \\
\hline 800 & 0.265 & 30.873 & $0.10073 \mathrm{E}+00$ & $0.16996 \mathrm{E}-02$ & $0.45477 \mathrm{E}-01$ & $0.96438 \mathrm{E}+02$ & $0.95742 \mathrm{E}+03$ & $120.6 \pm 1.1$ \\
\hline 870 & 0.325 & 18.177 & $0.50615 \mathrm{E}-01$ & $0.11357 \mathrm{E}-02$ & $0.31036 \mathrm{E}-01$ & $0.82314 \mathrm{E}+02$ & $0.16263 \mathrm{E}+04$ & $121.8 \pm 3.9$ \\
\hline 920 & 0.432 & 26.557 & $0.83566 \mathrm{E}-01$ & $0.37997 \mathrm{E}-05$ & $0.39642 \mathrm{E}-01$ & $0.93012 \mathrm{E}+02$ & $0.11130 \mathrm{E}+04$ & $123.5 \pm 0.8$ \\
\hline 1120 & 0.577 & 22.681 & $0.67276 \mathrm{E}-01$ & $0.29570 \mathrm{E}-03$ & $0.40495 \mathrm{E}-01$ & $0.87679 \mathrm{E}+02$ & $0.13033 \mathrm{E}+04$ & $122.6 \pm 0.8$ \\
\hline 1070 & 0.703 & 19.504 & $0.55915 \mathrm{E}-01$ & $0.19395 E-02$ & $0.41796 \mathrm{E}-01$ & $0.84745 E+02$ & $0.15156 \mathrm{E}+04$ & $123.3 \pm 0.9$ \\
\hline 1100 & 0.813 & 14.328 & $0.39039 \mathrm{E}-01$ & $0.36732 \mathrm{E}-05$ & $0.38863 \mathrm{E}-01$ & $0.80543 \mathrm{E}+02$ & $0.20631 E+04$ & $124.7 \pm 0.8$ \\
\hline 1150 & 0.959 & 11.189 & $0.29318 \mathrm{E}-01$ & $0.15145 \mathrm{E}-03$ & $0.32720 \mathrm{E}-01$ & $0.77455 \mathrm{E}+02$ & $0.26419 \mathrm{E}+04$ & $124.3 \pm 0.8$ \\
\hline 1200 & 1.000 & 19.538 & $0.54916 \mathrm{E}-01$ & $0.35175 \mathrm{E}-02$ & $0.32838 \mathrm{E}-01$ & $0.83086 \mathrm{E}+02$ & $0.15130 \mathrm{E}+04$ & $120.9 \pm 1.7$ \\
\hline
\end{tabular}

Sample mass $=103.4 \mathrm{mg}$

$J$ value $=0.00103754 \pm 0.00000615$

Integrated date $=122.9 \pm 0.8 \mathrm{Ma}$

Plateau date $=123.5 \pm 0.5 \mathrm{Ma}\left(550-1150{ }^{\circ} \mathrm{C}\right)$

$\begin{array}{lrrrr}\text { YE-4 (K-feldspar) } & & & \\ 550 & 0.190 & 26.344 & 0.9174 \mathrm{E}-01 & 0.1584 \mathrm{E}-01 \\ 600 & 0.317 & 3.467 & 0.9071 \mathrm{E}-02 & 0.1764 \mathrm{E}-01 \\ 650 & 0.418 & 0.004 & 0.1008 \mathrm{E}-04 & 0.2529 \mathrm{E}-02 \\ 700 & 0.504 & 0.120 & 0.3070 \mathrm{E}-03 & 0.1546 \mathrm{E}-01 \\ 750 & 0.560 & 3.154 & 0.7823 \mathrm{E}-02 & 0.5170 \mathrm{E}-01 \\ 800 & 0.601 & 0.008 & 0.2493 \mathrm{E}-04 & 0.1748 \mathrm{E}-01 \\ 850 & 0.646 & 0.007 & 0.2272 \mathrm{E}-04 & 0.1577 \mathrm{E}-01 \\ 900 & 0.683 & 3.574 & 0.8728 \mathrm{E}-02 & 0.1429 \mathrm{E}-01 \\ 950 & 0.753 & 10.320 & 0.2786 \mathrm{E}-01 & 0.2069 \mathrm{E}-01 \\ 1000 & 0.791 & 3.840 & 0.9781 \mathrm{E}-02 & 0.7130 \mathrm{E}-02 \\ 1057 & 0.847 & 3.948 & 0.1012 \mathrm{E}-01 & 0.1446 \mathrm{E}-01 \\ 1100 & 0.916 & 7.161 & 0.1931 \mathrm{E}-01 & 0.1516 \mathrm{E}-01 \\ 1150 & 0.991 & 21.478 & 0.6575 \mathrm{E}-01 & 0.1887 \mathrm{E}-01 \\ 1212 & 1.000 & 29.035 & 0.8567 \mathrm{E}-01 & 0.1174 \mathrm{E}-03\end{array}$

Sample mass $=38.0 \mathrm{mg}$

$J$ value $=0.0010427 \pm 0.0000412$

Integrated date $=133.4 \pm 0.7 \mathrm{Ma}$

Plateau date $=133.6 \pm 0.7 \mathrm{Ma}\left(550-1150{ }^{\circ} \mathrm{C}\right)$

$0.3595 \mathrm{E}-01$
$0.1497 \mathrm{E}-01$
$0.1814 \mathrm{E}-01$
$0.1321 \mathrm{E}-01$
$0.2227 \mathrm{E}-01$
$0.2329 \mathrm{E}-01$
$0.2004 \mathrm{E}-01$
$0.1957 \mathrm{E}+01$
$0.2752 \mathrm{E}-01$
$0.2701 \mathrm{E}-01$
$0.3673 \mathrm{E}-01$
$0.3556 \mathrm{E}-01$
$0.4370 \mathrm{E}-01$
$0.1174 \mathrm{E}+00$

$0.1029 \mathrm{E}+03$

$0.7731 \mathrm{E}+02$

$0.7525 \mathrm{E}+02$

$0.7492 \mathrm{E}+02$

$0.7321 \mathrm{E}+02$

$0.7270 \mathrm{E}+02$

$0.7436 \mathrm{E}+02$

$0.7215 \mathrm{E}+02$

$0.7980 \mathrm{E}+02$

$0.7528 \mathrm{E}+02$

$0.7574 \mathrm{E}+02$

$0.7968 \mathrm{E}+02$

$0.9048 \mathrm{E}+02$

$0.8722 \mathrm{E}+02$
$0.1122 \mathrm{E}+04$
$0.8522 \mathrm{E}+04$
$0.7467 \mathrm{E}+07$
$0.2440 \mathrm{E}+06$
$0.9357 \mathrm{E}+04$
$0.2916 \mathrm{E}+07$
$0.3273 \mathrm{E}+07$
$0.8267 \mathrm{E}+04$
$0.2864 \mathrm{E}+04$
$0.7697 \mathrm{E}+04$
$0.7485 \mathrm{E}+04$
$0.4127 \mathrm{E}+04$
$0.1376 \mathrm{E}+04$
$0.1018 \mathrm{E}+04$

$137.2 \pm 0.8$

$135.1 \pm 1.2$

$136.2 \pm 0.9$

$135.5 \pm 0.8$

$128.6 \pm 1.9$

$131.8 \pm 2.4$

$134.7 \pm 2.5$

$126.3 \pm 3.5$

$129.8 \pm 1.9$

$131.2 \pm 4.6$

$131.9 \pm 3.3$

$134.0 \pm 1.9$

$128.9 \pm 1.2$

$112.8 \pm 11.6$

$\begin{array}{lrrll}L-1 & \text { (K-feldspar) } & & & \\ 550 & 0.069 & 46.211 & 0.27035 \mathrm{E}+00 & 0.97914 \mathrm{E}-05 \\ 600 & 0.102 & 20.655 & 0.65419 \mathrm{E}-01 & 0.20976 \mathrm{E}-04 \\ 650 & 0.127 & 29.260 & 0.99307 \mathrm{E}-01 & 0.26442 \mathrm{E}-04 \\ 700 & 0.155 & 29.253 & 0.96011 \mathrm{E}-01 & 0.24074 \mathrm{E}-04 \\ 750 & 0.179 & 29.641 & 0.88354 \mathrm{E}-01 & 0.71556 \mathrm{E}-02 \\ 800 & 0.203 & 30.875 & 0.10037 \mathrm{E}+00 & 0.28653 \mathrm{E}-04 \\ 850 & 0.231 & 32.140 & 0.10307 \mathrm{E}+00 & 0.54013 \mathrm{E}-02 \\ 900 & 0.266 & 18.877 & 0.53484 \mathrm{E}-01 & 0.31758 \mathrm{E}-02 \\ 950 & 0.310 & 12.901 & 0.34234 \mathrm{E}-01 & 0.15420 \mathrm{E}-04 \\ 1000 & 0.376 & 12.860 & 0.34697 \mathrm{E}-01 & 0.21055 \mathrm{E}-02 \\ 1050 & 0.467 & 11.619 & 0.31679 \mathrm{E}-01 & 0.32355 \mathrm{E}-03 \\ 1100 & 0.573 & 18.218 & 0.53101 \mathrm{E}-01 & 0.27817 \mathrm{E}-02\end{array}$

\begin{abstract}
$0.91580 \mathrm{E}-01$
$0.32957 \mathrm{E}-01$

$0.44735 \mathrm{E}-01$

$0.40002 \mathrm{E}-01$

$0.31387 \mathrm{E}-01$

$0.27446 \mathrm{E}-01$

$0.39086 \mathrm{E}-01$

$0.27349 \mathrm{E}-01$

$0.29150 \mathrm{E}-01$

$0.27692 \mathrm{E}-01$

$0.26027 \mathrm{E}-01$

$0.30949 \mathrm{E}-01$

$0.17291 \mathrm{E}+03$ $0.93619 \mathrm{E}+02$ $0.10032 \mathrm{E}+03$ $0.97015 \mathrm{E}+02$ $0.88110 \mathrm{E}+02$ $0.96092 \mathrm{E}+02$ $0.94793 \mathrm{E}+02$ $0.83750 \mathrm{E}+02$ $0.78441 \mathrm{E}+02$ $0.79754 \mathrm{E}+02$ $0.80593 \mathrm{E}+02$ $0.86159 \mathrm{E}+02$
\end{abstract}

$0.63956 \mathrm{E}+03$ $0.14311 \mathrm{E}+04$ $0.10102 \mathrm{E}+04$ $0.10105 \mathrm{E}+04$ $0.99724 \mathrm{E}+03$ $0.95738 \mathrm{E}+03$ $0.91967 \mathrm{E}+03$ $0.15659 \mathrm{E}+04$ $0.22913 \mathrm{E}+04$ $0.22986 \mathrm{E}+04$ $0.25441 \mathrm{E}+04$ $0.16225 \mathrm{E}+04$
$167.3 \pm 1.8$

$134.8 \pm 2.6$ $129.0 \pm 3.3$ $124.9 \pm 2.9$

$113.2 \pm 3.5$

$121.0 \pm 2.8$

$117.3 \pm 1.7$

$123.7 \pm 2.6$

$124.4 \pm 1.4$

$126.4 \pm 2.0$

$129.5 \pm 1.0$

$128.1 \pm 0.9$ 
Table 5 (continued)

\begin{tabular}{|c|c|c|c|c|c|c|c|c|}
\hline$T\left({ }^{\circ} \mathrm{C}\right)$ & $\begin{array}{l}\text { Cum. } \\
{ }^{39} \mathrm{Ar}_{\mathrm{K}}\end{array}$ & $\begin{array}{l}\text { Atmos. } \\
(\%)\end{array}$ & ${ }^{36} \mathrm{Ar} /{ }^{39} \mathrm{Ar}$ & ${ }^{37} \mathrm{Ar} /{ }^{39} \mathrm{Ar}$ & ${ }^{38} \mathrm{Ar} /{ }^{39} \mathrm{Ar}$ & ${ }^{40} \mathrm{Ar} /{ }^{39} \mathrm{Ar}$ & ${ }^{40} \mathrm{Ar} /{ }^{36} \mathrm{Ar}$ & Date (Ma) \\
\hline \multicolumn{9}{|c|}{ L-1 (K-feldspar) } \\
\hline 1150 & 0.885 & 24.346 & $0.77465 \mathrm{E}-01$ & $0.10814 \mathrm{E}-02$ & $0.35434 \mathrm{E}-01$ & $0.94051 \mathrm{E}+02$ & $0.12141 \mathrm{E}+04$ & $129.3 \pm 0.8$ \\
\hline 1200 & 1.000 & 27.179 & $0.88696 \mathrm{E}-01$ & $0.14392 \mathrm{E}-02$ & $0.37492 \mathrm{E}-01$ & $0.96463 \mathrm{E}+02$ & $0.10876 \mathrm{E}+04$ & $127.8 \pm 1.0$ \\
\hline \multicolumn{9}{|c|}{ Sample mass $=100.2 \mathrm{mg}$} \\
\hline \multicolumn{9}{|c|}{$J$ value $=0.00104493 \pm 0.00000615$} \\
\hline \multicolumn{9}{|c|}{ Integrated date $=130.2 \pm 0.8 \mathrm{Ma}$} \\
\hline \multicolumn{9}{|c|}{ Plateau date $=128.0 \pm 0.6 \mathrm{Ma}\left(900-1150{ }^{\circ} \mathrm{C}\right)$} \\
\hline \multicolumn{9}{|c|}{$L-4$ (K-feldspar) } \\
\hline 550 & 0.222 & 18.711 & $0.5156 \mathrm{E}-01$ & $0.4303 \mathrm{E}-02$ & $0.2263 \mathrm{E}-01$ & $0.8145 \mathrm{E}+02$ & $0.1580 \mathrm{E}+04$ & $120.4 \pm 0.5$ \\
\hline 600 & 0.312 & 3.050 & $0.7042 \mathrm{E}-02$ & $0.1011 \mathrm{E}-01$ & $0.1539 \mathrm{E}-01$ & $0.6824 \mathrm{E}+02$ & $0.9690 \mathrm{E}+04$ & $120.3 \pm 0.6$ \\
\hline 650 & 0.377 & 1.844 & $0.4220 \mathrm{E}-02$ & $0.8546 \mathrm{E}-02$ & $0.1590 \mathrm{E}-01$ & $0.6762 \mathrm{E}+02$ & $0.1602 \mathrm{E}+05$ & $120.7 \pm 0.8$ \\
\hline 700 & 0.418 & 3.449 & $0.7884 \mathrm{E}-02$ & $0.1246 \mathrm{E}-01$ & $0.1532 \mathrm{E}-01$ & $0.6755 E+02$ & $0.8568 \mathrm{E}+04$ & $118.7 \pm 0.8$ \\
\hline 750 & 0.449 & 2.045 & $0.4631 \mathrm{E}-02$ & $0.1654 \mathrm{E}-01$ & $0.1721 \mathrm{E}-01$ & $0.6689 \mathrm{E}+02$ & $0.1444 \mathrm{E}+05$ & $119.2 \pm 1.1$ \\
\hline 800 & 0.470 & 7.703 & $0.1767 \mathrm{E}-01$ & $0.3680 \mathrm{E}-01$ & $0.3715 \mathrm{E}-01$ & $0.6779 \mathrm{E}+02$ & $0.3836 \mathrm{E}+04$ & $114.0 \pm 2.0$ \\
\hline 850 & 0.495 & 6.527 & $0.1536 \mathrm{E}-01$ & $0.4395 E-01$ & $0.1625 \mathrm{E}-01$ & $0.6952 \mathrm{E}+02$ & $0.4526 \mathrm{E}+04$ & $118.2 \pm 1.8$ \\
\hline 900 & 0.523 & 8.002 & $0.1943 E-01$ & $0.1324 \mathrm{E}-03$ & $0.2077 \mathrm{E}-01$ & $0.7179 \mathrm{E}+02$ & $0.3695 \mathrm{E}+04$ & $120.1 \pm 1.2$ \\
\hline 950 & 0.563 & 9.298 & $0.2283 \mathrm{E}-01$ & $0.9601 \mathrm{E}-02$ & $0.2002 \mathrm{E}-01$ & $0.7258 \mathrm{E}+02$ & $0.3179 \mathrm{E}+04$ & $119.7 \pm 1.0$ \\
\hline 1000 & 0.604 & 10.456 & $0.2539 \mathrm{E}-01$ & $0.3106 \mathrm{E}-01$ & $0.1980 \mathrm{E}-01$ & $0.7175 E+02$ & $0.2826 \mathrm{E}+04$ & $116.9 \pm 1.5$ \\
\hline 1050 & 0.646 & 6.519 & $0.1549 \mathrm{E}-01$ & $0.1383 \mathrm{E}-01$ & $0.1785 \mathrm{E}-01$ & $0.7022 \mathrm{E}+02$ & $0.4534 \mathrm{E}+04$ & $119.4 \pm 1.0$ \\
\hline 1100 & 0.695 & 4.758 & $0.1121 \mathrm{E}-01$ & $0.1627 E-01$ & $0.1811 \mathrm{E}-01$ & $0.6966 \mathrm{E}+02$ & $0.6211 \mathrm{E}+04$ & $120.6 \pm 1.5$ \\
\hline 1150 & 0.885 & 6.780 & $0.1681 \mathrm{E}-01$ & $0.1013 \mathrm{E}-01$ & $0.1753 \mathrm{E}-01$ & $0.7329 E+02$ & $0.4360 \mathrm{E}+04$ & $124.1 \pm 0.6$ \\
\hline 1200 & 1.000 & 11.146 & $0.2865 \mathrm{E}-01$ & $0.4716 \mathrm{E}-02$ & $0.2038 \mathrm{E}-01$ & $0.7599 \mathrm{E}+02$ & $0.2652 \mathrm{E}+04$ & $122.7 \pm 0.5$ \\
\hline
\end{tabular}

Sample mass $=103.4 \mathrm{mg}$

$J$ value $=0.0010427 \pm 0.00000412$

Integrated date $=120.9 \pm 0.5 \mathrm{Ma}$

Plateau date $=120.9 \pm 0.5 \mathrm{Ma}\left(550-1200{ }^{\circ} \mathrm{C}\right)$

$J$ value: Weighted mean of one fusion of irradiation standard LP-6 Biotite, having a K-Ar age of $127.7 \pm 1.4$ Ma (Odin et al., 1982).

$T\left({ }^{\circ} \mathrm{C}\right)=$ Temperature with uncertainty of $\pm 2{ }^{\circ} \mathrm{C}$.

The date is obtained by using the following equations:

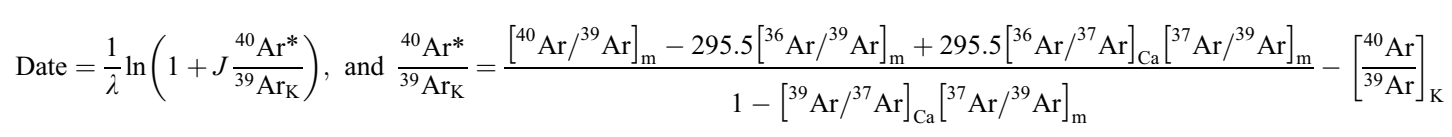

where []$_{\mathrm{Ca}}$ and []$_{\mathrm{K}}=$ isotope ratios of argon extracted from irradiated calcium and potassium salts (values cited in the text) and [ $]_{\mathrm{m}}=\mathrm{isotope}$ ratio of argon extracted from irradiated unknown.

Date $(\mathrm{Ma})=$ the date calculated using the following decay constants: $\lambda_{\varepsilon}=0.581 \times 10^{-10}$ year $^{-1} ; \lambda_{\beta}=4.962 \times 10^{-10}$ year $^{-1} ; \lambda=5.543 \times 10^{-10}$ year ${ }^{-1} ;{ }^{40} \mathrm{~K} / \mathrm{K}=0.01167$ at.\% (Steiger and Jäger, 1977).

Uncertainty for ${ }^{40} \mathrm{Ar}^{*}$ and ${ }^{39} \mathrm{Ar}_{\mathrm{K}}$ volumes are $\pm 5 \%$.

Cum. ${ }^{39} \mathrm{Ar}=$ cumulative fractions of ${ }^{39} \mathrm{Ar}_{\mathrm{K}}$ and ${ }^{40} \mathrm{Ar} *$ released in each step.

The quoted error is one standard deviation and does not include the error in the standard error, or the error in the interference corrections. Integrated Date $=$ the date and error calculated from the sum total gas from all steps; the error includes the error in $J$ value.

Plateau Date $=$ the data and error calculated from the sum total gas from those steps, the ages of which fall within 2 S.D. of each other; the error includes the error in $J$ value.

strained ${ }^{206} \mathrm{~Pb} /{ }^{238} \mathrm{U}$ age of $137 \pm 2$ Ma. The zircons are stubby with some oscillatory zoning, indicative of a magmatic origin. The slightly younger population at $123 \pm 6 \mathrm{Ma}$ are morphologically similar, but generally have higher $\mathrm{U}$ and $\mathrm{Th}$ concentrations and $\mathrm{Th} / \mathrm{U}$ ratios $>1.0$. Together with the younger grain of $112 \pm 3 \mathrm{Ma}$, they probably reflect various amounts of recent $\mathrm{Pb}$ loss, although it should be noted that they remain 

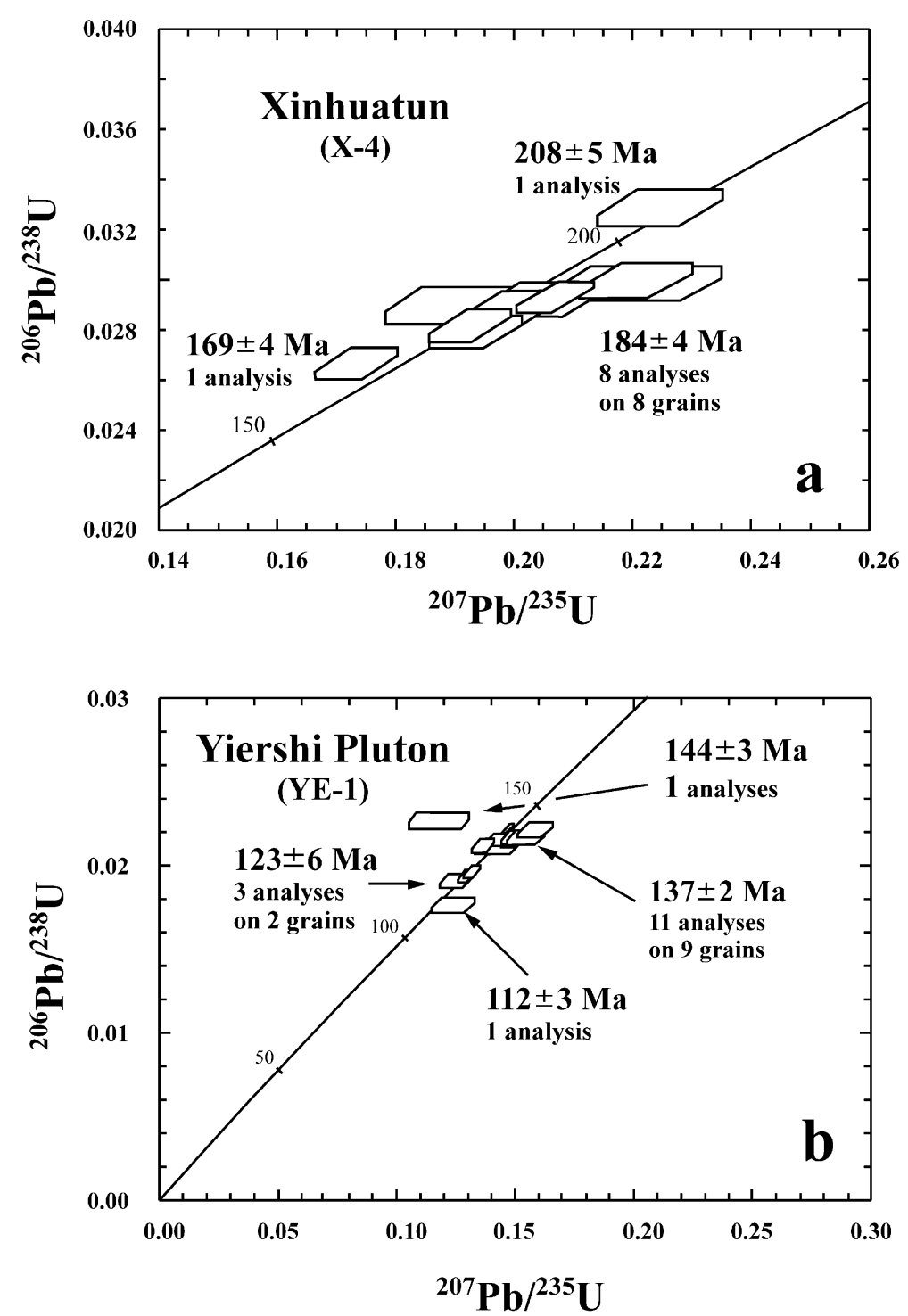

Fig. 5. U-Pb concordia diagram for the granites in NE China. (a) X-4 (Xinhuatun Pluton); (b) YE-1 (Yiershi Pluton).

reasonably concordant. We therefore interpret the weighted mean age of $137 \pm 2 \mathrm{Ma}$ for the main zircon population as representing the time of granitic emplacement.

Nine WR samples defined a $\mathrm{Rb}-\mathrm{Sr}$ WR isochron age of $143 \pm 5$ Ma with $\left({ }^{87} \mathrm{Sr} /{ }^{86} \mathrm{Sr}\right)_{\mathrm{i}}=0.7049 \pm 6$ (MSWD=7.7; Fig. 9a). The $\mathrm{Rb}-\mathrm{Sr}$ isochron age is identical with the zircon age within the error limits.
Although sample YE-1 had undergone intense weathering as suggested by $\mathrm{O}$ isotope (see the companion paper), the weathering has apparently not disturbed the $\mathrm{Rb}-\mathrm{Sr}$ isotopic system. BiotiteWR isochrons for samples YE-3 and YE-5 give ages of $133 \pm 3 \mathrm{Ma}\left(\left({ }^{87} \mathrm{Sr} /{ }^{86} \mathrm{Sr}\right)_{\mathrm{i}}=0.7065 \pm 4\right.$, Fig. $\left.9 \mathrm{~b}\right)$ and $134 \pm 3 \mathrm{Ma}\left(\left({ }^{87} \mathrm{Sr} /{ }^{86} \mathrm{Sr}\right)_{\mathrm{i}}=0.7053 \pm 4\right.$, Fig. $\left.9 \mathrm{c}\right)$, respectively. $\mathrm{Ar}-\mathrm{Ar}$ analyses of $\mathrm{K}$-feldspar separates 

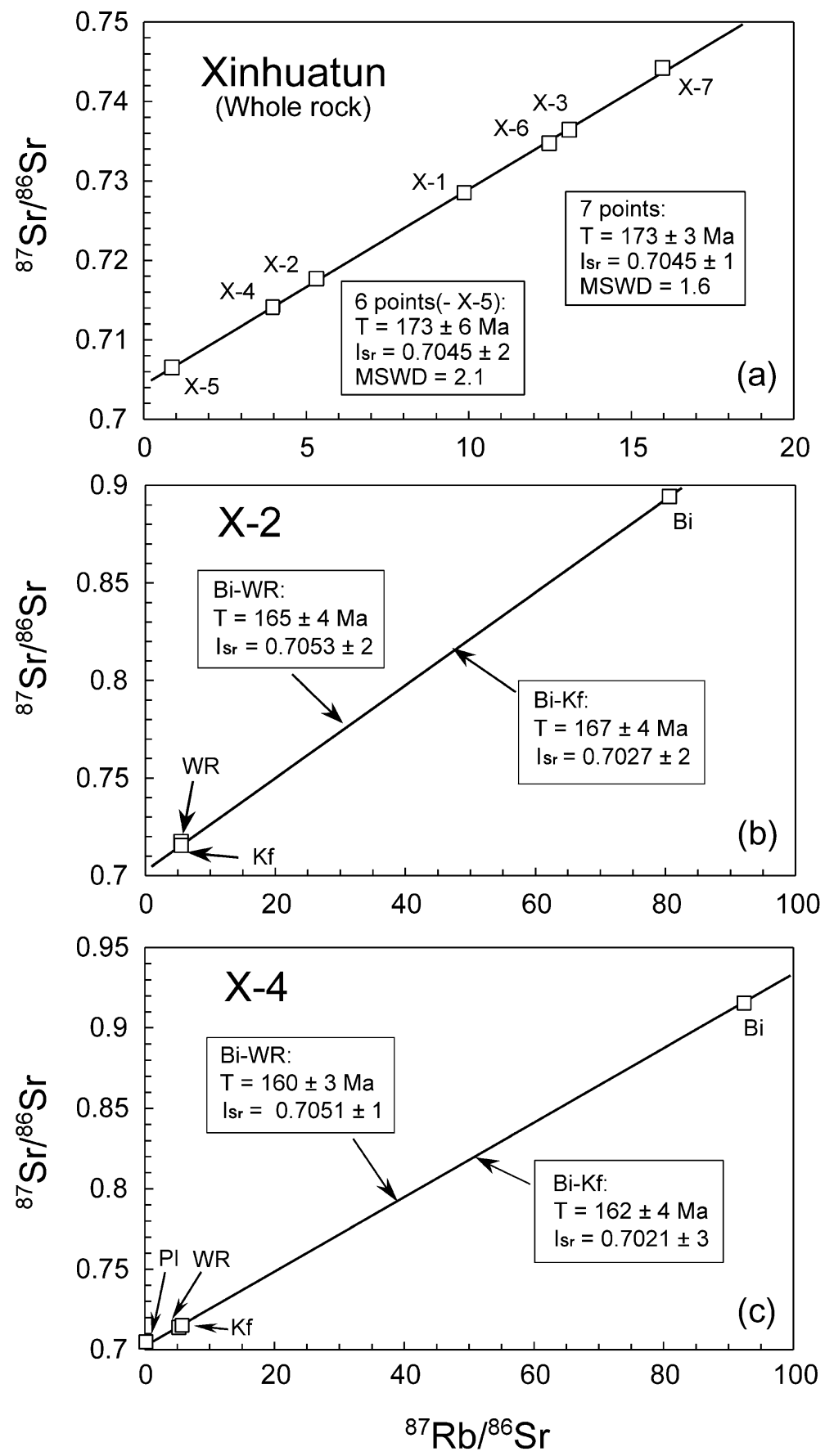

Fig. 6. $\mathrm{Rb}-\mathrm{Sr}$ isochron diagrams of the Xinhuatun Pluton. (a) Whole-rock (WR) isochron; (b) and (c): internal isochrons for samples X-2 and $\mathrm{X}-4$, respectively. 


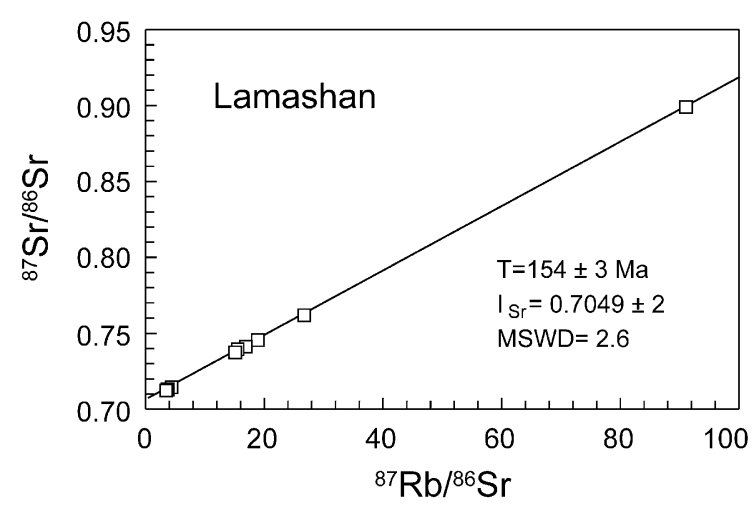

Fig. 7. $\mathrm{Rb}-\mathrm{Sr} \mathrm{WR}$ isochron diagram of the Lamashan Pluton.

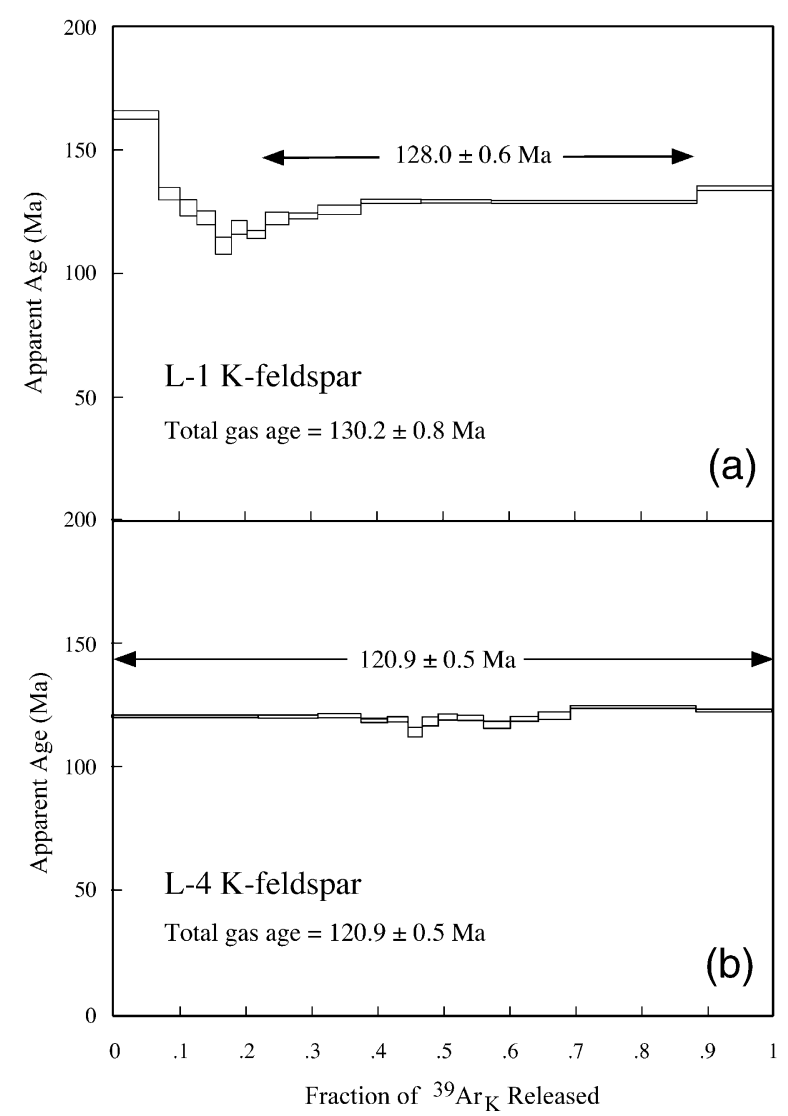

from two granite samples (YE-1 and YE-4) yield plateau ages of $123.5 \pm 0.5$ and $133.6 \pm 0.7 \mathrm{Ma}$, respectively (Fig. 10a and b). In the isotope correlation diagrams, regression of data for plateau steps gives intercept ages of $125.8 \pm 0.8$ and $133.6 \pm 0.7$ $\mathrm{Ma}$, which are in complete agreement with their respective plateau ages (Fig. 10c and d). The Ar ages of YE-4 are identical to the biotite $\mathrm{Rb}-\mathrm{Sr}$ ages, but the Ar age of sample YE-1 is the same as the second group of zircon ages in the same sample, which indicates that each individual sample has a different cooling history. If the younger age of 126 Ma is taken, then a cooling rate of $45^{\circ} \mathrm{C} / \mathrm{Ma}$ (early) to $20{ }^{\circ} \mathrm{C} / \mathrm{Ma}$ (late) is obtained.

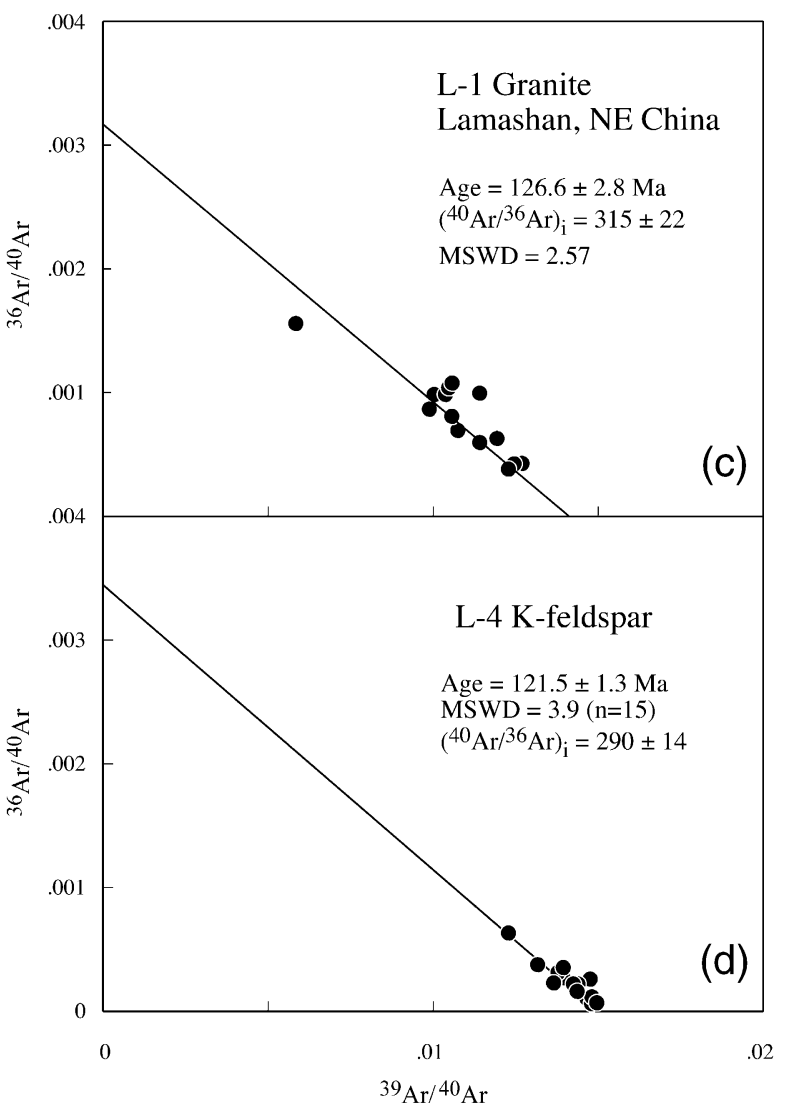

Fig. $8 .{ }^{40} \mathrm{Ar} /{ }^{39} \mathrm{Ar}$ age spectra and ${ }^{36} \mathrm{Ar} /{ }^{40} \mathrm{Ar}-{ }^{39} \mathrm{Ar} /{ }^{40} \mathrm{Ar}$ isotope correlation diagrams for K-feldspars extracted from two samples of the Lamashan Pluton. In the age spectra (a and b), boxes represent the relative fraction of ${ }^{39} \mathrm{Ar}_{\mathrm{K}}$ released in heating steps and extend vertically to $\pm 1 \sigma$. In the isotope correlation diagrams ( $\mathrm{c}$ and $\mathrm{d}$ ), solid circles indicate the gas compositions for plateau steps, which were incorporated into the data regression. Error ellipses represent $\pm 1 \sigma$. 
(a)

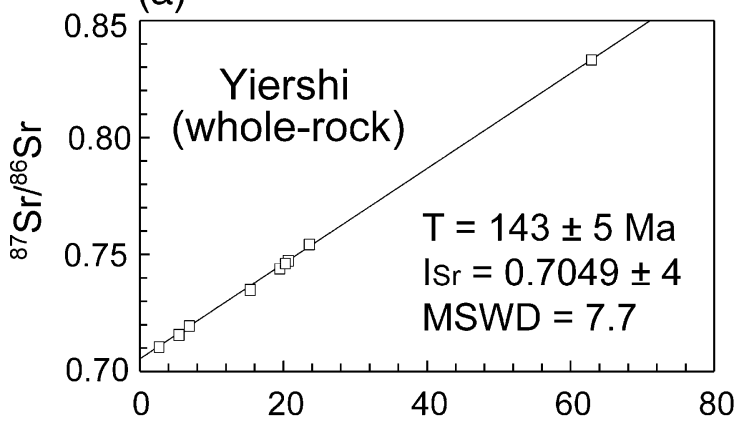

(b)

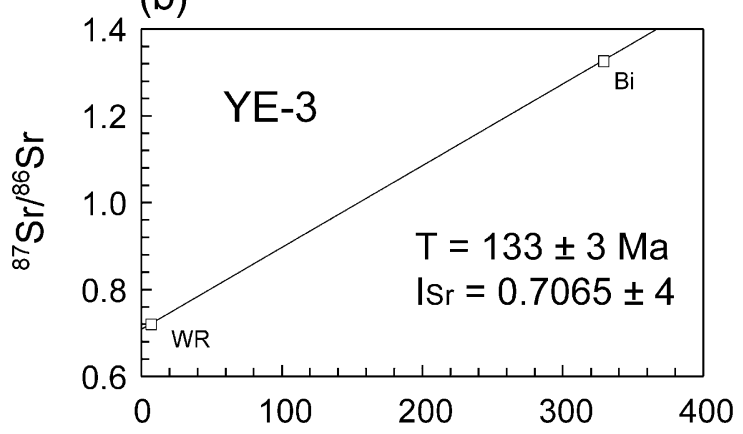

(c)

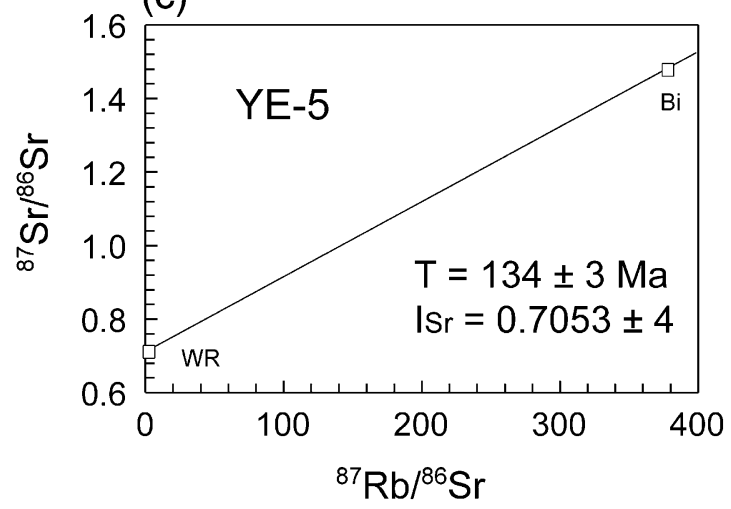

Fig. 9. $\mathrm{Rb}-\mathrm{Sr} \mathrm{WR}$ isochron diagram of the Yiershi Pluton. (a) WR $\mathrm{Rb}-\mathrm{Sr}$ isochron; (b) and (c): biotite-WR isochrons for samples YE-3 and YE-5, respectively.

The above age pattern, namely, zircon $\mathrm{U}-\mathrm{Pb}$ age $\approx$ WR $\mathrm{Rb}-\mathrm{Sr}$ isochron age $>$ biotite-WR $\mathrm{Rb}-\mathrm{Sr}$ isochron age $>$ feldspar ${ }^{40} \mathrm{Ar} /{ }^{39} \mathrm{Ar}$ age, has been found to be systematic in granitic plutons since mineral ages often record the cooling history of the rocks, whereas zircon $\mathrm{U}-\mathrm{Pb}$ and whole-rock $\mathrm{Rb}-\mathrm{Sr}$ isochron ages are taken to reflect the emplacement age. In addition, the flat age spectra and the consistency between the plateau and intercept ages suggest that since the closure of the Ar isotope clock, the samples have not been significantly disturbed by later-stage events. They have only experienced a simple cooling history since their emplacement (Harrison, 1990).

The cooling histories of the three plutons are summarized in Fig. 11. Assuming magmatic intrusion temperatures of $800-700{ }^{\circ} \mathrm{C}$ (Chappell et al., 2000), the earlier-formed Xinhuatun and Lamashan plutons seem to have slower cooling rates than the later Yiershi pluton, at least in the initial stage when biotite was cooled to its blocking temperature of ca. 300$250{ }^{\circ} \mathrm{C}$ (Jager et al., 1967). This was followed by a lower cooling rate of ca. $20{ }^{\circ} \mathrm{C} / \mathrm{Ma}$. The Lamashan pluton has no biotite age as a constraint, but it probably had the slowest cooling rate and longest cooling time $(\Delta t=$ ca. $30 \mathrm{Ma})$ from emplacement to the closure of $\mathrm{K}$-feldspar $\mathrm{K}-\mathrm{Ar}$ isotope systems ( 150-200 ${ }^{\circ} \mathrm{C}$; McDougall and Harrison, 1988).

Combining our present and recent age data with previous work in this region (Fang, 1992; HBGMR, 1993; Wu et al., 2002), it can be concluded that Phanerozoic granitic emplacement in NE China took place from the late Paleozoic to late Mesozoic, with culmination in the period of $210-140 \mathrm{Ma}$. This is about 120 to $140 \mathrm{Ma}$ younger than the widespread post-orogenic A-type granites (300-280 Ma) in Northern Xinjiang, central Inner Mongolia and the Great Xing'an Ranges (Hong et al., 1994; Wang et al., 1994; Han et al., 1997; Sun et al., 2001).

Precise age determination is of utmost importance for any tectonic evolution models. Sengör et al. (1993) and Sengör and Natal'in (1996a,b) published a series of papers on the evolution of the Central Asian Orogenic Belt and used the "magmatic front" as a new type of structural marker in their reconstruction of tectonic evolution. However, available precise age data were scarce, and the validity of the "magmatic front" concept based on old age information was severely hampered. In NE China, most granites were assigned late Paleozoic ages ( $\mathrm{Li}$ and Zhao, 1984), but more recently, they have been reassigned as Indosinian (ca. $200 \mathrm{Ma}$ ) on the basis of a few imprecise whole-rock $\mathrm{Rb}-\mathrm{Sr}$ isochron dates (HBGMR, 1993). The new age data presented here and those published in Wu et al. (2002) clearly show 

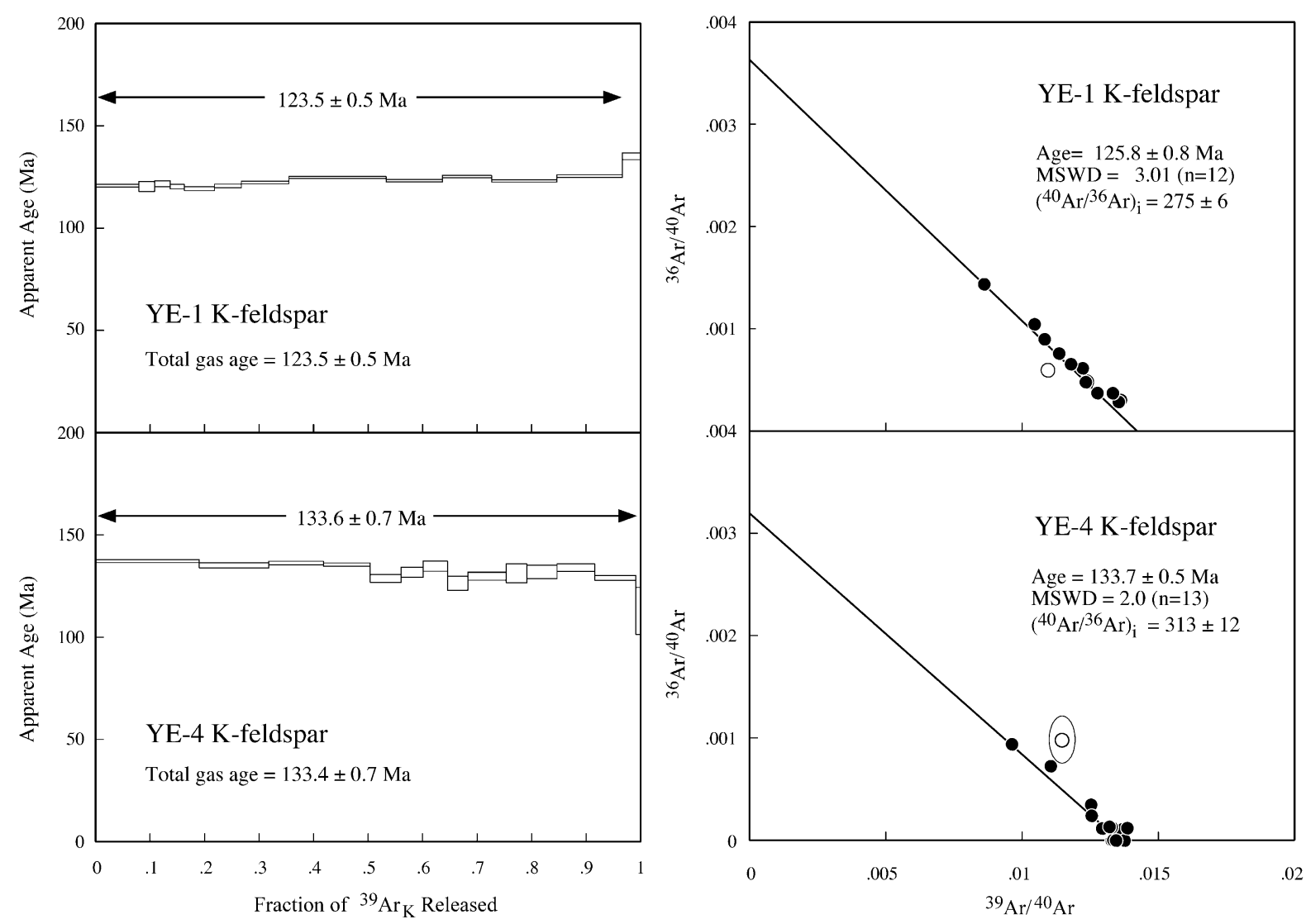

Fig. 10. ${ }^{40} \mathrm{Ar} /{ }^{39} \mathrm{Ar}$ age spectra and ${ }^{36} \mathrm{Ar} /{ }^{40} \mathrm{Ar}-{ }^{39} \mathrm{Ar} /{ }^{40} \mathrm{Ar}$ isotope correlation diagrams for $\mathrm{K}$-feldspars extracted from samples of the Yiershi Pluton. All notations are the same as in Fig. 8.

that many of the earlier dates were erroneously assigned. Therefore, until further precise age data are obtained, any tectonic model based on the magmatic front model must involve a large uncertainty.

\section{Petrogenesis}

\subsection{Genetic type: I-type or A-type?}

Since the introduction of the terms "I-" and "Stype" granite by Chappell and White (1974), granitic rocks have commonly been divided into I-, S-, Mand A-types according to their protolith nature (Pitcher, 1982, 1993). However, distinction between different types is not always easy. This is particularly true for the case of A-type and highly differentiated I-type granites (White and Chappell, 1983; Chappell and Stephens, 1988; Chappell and White, 1992, 2001; Champion and Chappell, 1992; Landenberger and Collins, 1996; King et al., 1997, 2001). Several attempts have been made to discriminate A-types from the others (I-, S- and M-type) (e.g., Loiselle and Wones, 1979; Collins et al., 1982; Whalen et al., 1987, 1996; Sylvester, 1989; Eby, 1990, 1992). In general, A-type granites are emplaced later than I-types and they are comparatively enriched in HFSEs (high field strength element), such as $\mathrm{Zr}$, $\mathrm{Nb}, \mathrm{Y}, \mathrm{REE}$ and $\mathrm{Ga}$, although significant compositional overlap is also observed; for example, an early recognition of the importance of $\mathrm{Ga}$ enrichment 


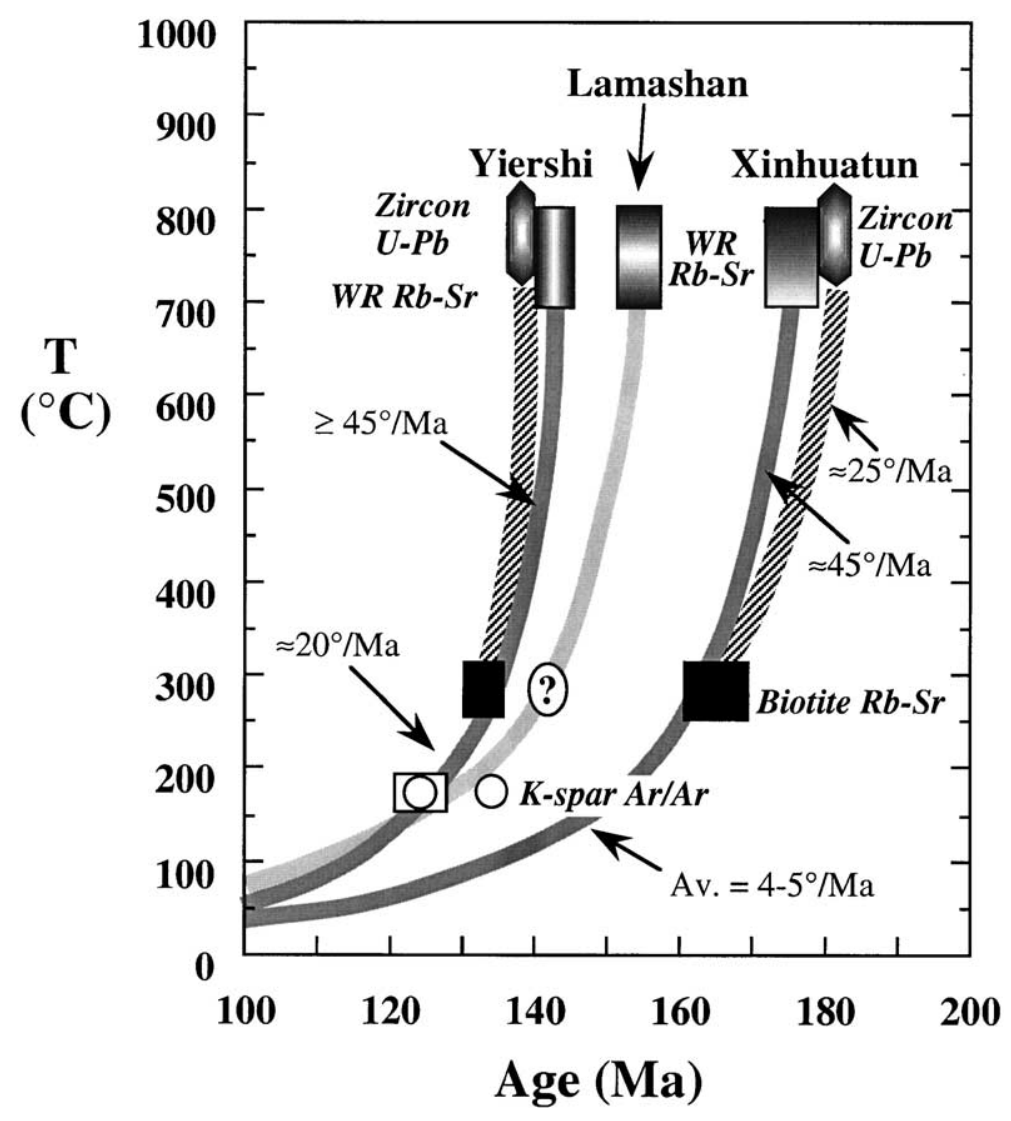

Fig. 11. Cooling paths of the three plutons.

(relative to $\mathrm{Al}$ ) has persisted in most subsequent studies.

The granites in this study are peraluminous; most of them have $\mathrm{A} / \mathrm{CNK}<1.1$, normative corundum $<1 \%$ and $\mathrm{A} / \mathrm{NK}>1.0$. It is also shown that $\mathrm{P}_{2} \mathrm{O}_{5}$ decreases with increasing $\mathrm{SiO}_{2}$, whereas $\mathrm{Pb}$ moves in the opposite direction (Fig. 12). This feature is considered as an important criterion for distinction of I- from S-type granitoids by Chappell and White (1992). Combined with the Sr isotopic data, it is clear that the granites under study are not S-type but they belong to I- or A-types.

The granites in NE China have some similarities to A-type in their field and petrographic characteristics. However, they do not contain mafic alkaline minerals such as arfvedsonite, riebeckite, etc. The relatively low contents of $\mathrm{Zr}, \mathrm{Nb}, \mathrm{Y}, \mathrm{La}, \mathrm{Ce}, \mathrm{Zn}$ and
Ga strongly suggest that they belong to I-type. As proposed by Whalen et al. (1987), in some discrimination diagrams of $\mathrm{K}_{2} \mathrm{O}+\mathrm{Na}_{2} \mathrm{O}, \mathrm{FeO}^{*} / \mathrm{MgO}, \mathrm{Nb}$ and $\mathrm{Zr}$ vs. $\mathrm{Ga} / \mathrm{Al}$ (Fig. $13 \mathrm{a}-\mathrm{d}$ ), the granites straddle the fields of A- and M-, I-, S-types with small variation in $\mathrm{Ga} / \mathrm{Al}$ ratios. Furthermore, in $\mathrm{FeO}^{*} /$ $\mathrm{MgO}$ and $\left(\mathrm{K}_{2} \mathrm{O}+\mathrm{Na}_{2} \mathrm{O}\right) / \mathrm{CaO}$ vs. $(\mathrm{Zr}+\mathrm{Nb}+\mathrm{Ce}+\mathrm{Y})$ diagrams (Fig. 13e and $\mathrm{f}$ ), most of these granites fall in the field of highly fractionated I-type. This is also confirmed by the criteria of Sylvester (1989) using the diagram of $\left(\mathrm{Al}_{2} \mathrm{O}_{3}+\mathrm{CaO}\right) /\left(\mathrm{FeO}^{*}+\mathrm{Na}_{2} \mathrm{O}+\mathrm{K}_{2} \mathrm{O}\right)$ vs. $100\left(\mathrm{MgO}+\mathrm{FeO}^{*}+\mathrm{TiO}_{2}\right) / \mathrm{SiO}_{2}$ (not shown here), which is fairly effective in discriminating alkaline granites from calc-alkaline and strongly peraluminous granites. We therefore conclude that the granites described in this study are highly fractionated I-type granites. 


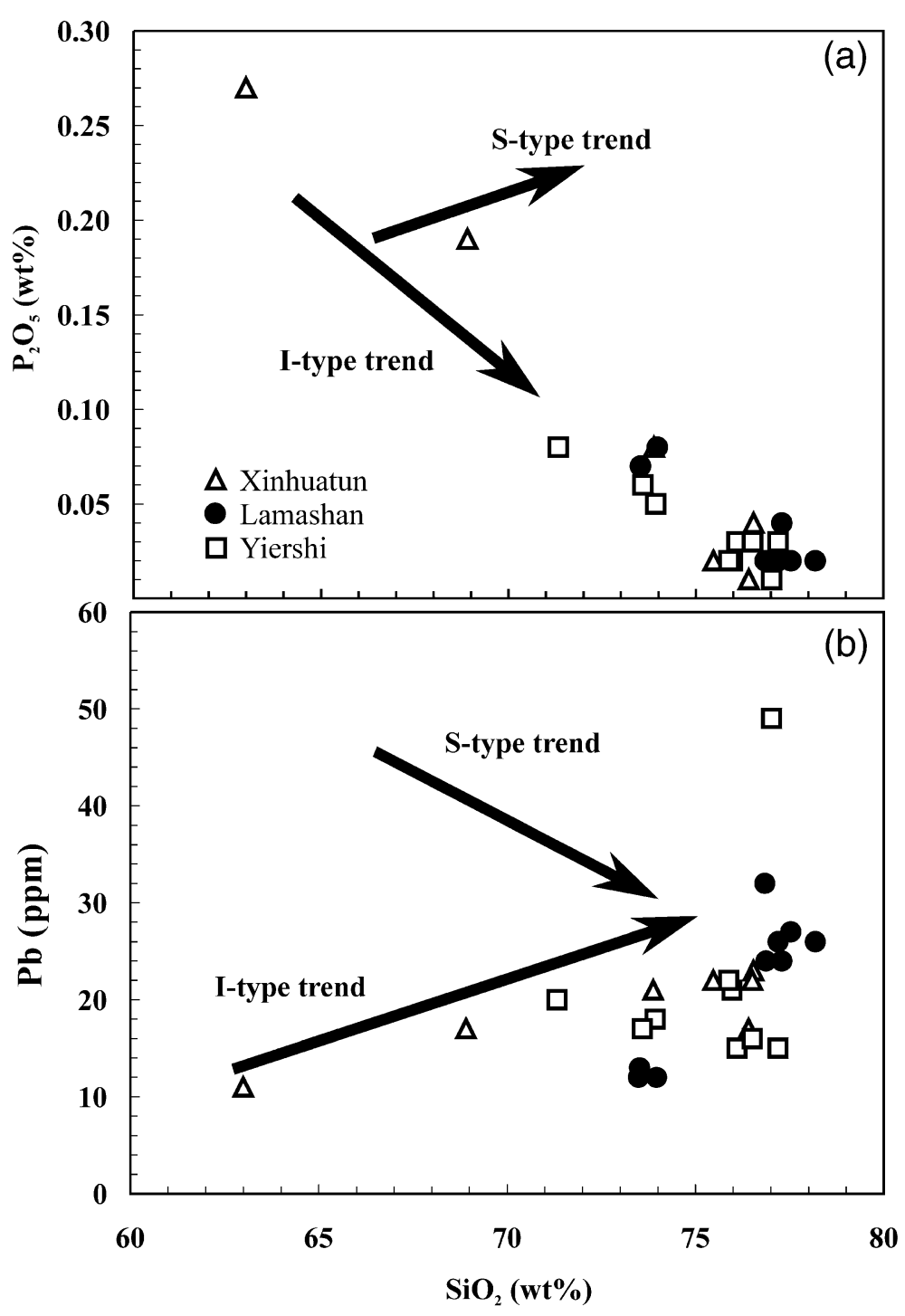

Fig. 12. (a) $\mathrm{P}_{2} \mathrm{O}_{5}$ vs. $\mathrm{SiO}_{2}$ and (b) $\mathrm{Pb}$ vs. $\mathrm{SiO}_{2}$ variation diagrams showing that the granites follow the trend of I-type proposed by Chappell and White (1992).

\subsection{Fractionation processes}

Advanced fractional crystallization has taken place during the formation of these granites. This is supported by the striking depletions in $\mathrm{Ba}, \mathrm{Sr}, \mathrm{Nb}$, $\mathrm{P}, \mathrm{Ti}$ and Eu shown in the spidergrams (Fig. 4). Negative $\mathrm{Nb}-\mathrm{Ti}$ anomalies are considered to be related to fractionation of Ti-bearing phases (ilmen- ite, titanite, etc.) and negative $\mathrm{P}$ anomalies should result from apatite separation. Strong Eu depletion requires extensive fractionation of plagioclase and/or K-feldspar. Fractionation of plagioclase would result in negative $\mathrm{Sr}-\mathrm{Eu}$ anomalies, and that of $\mathrm{K}$-feldspar would produce negative $\mathrm{Eu}-\mathrm{Ba}$ anomalies.

Generally, as $\mathrm{SiO}_{2}$ increases, total REE, $\mathrm{Sr}$ and $\mathrm{Ba}$ contents decrease, whereas the $\mathrm{Rb}$ content is fairly 

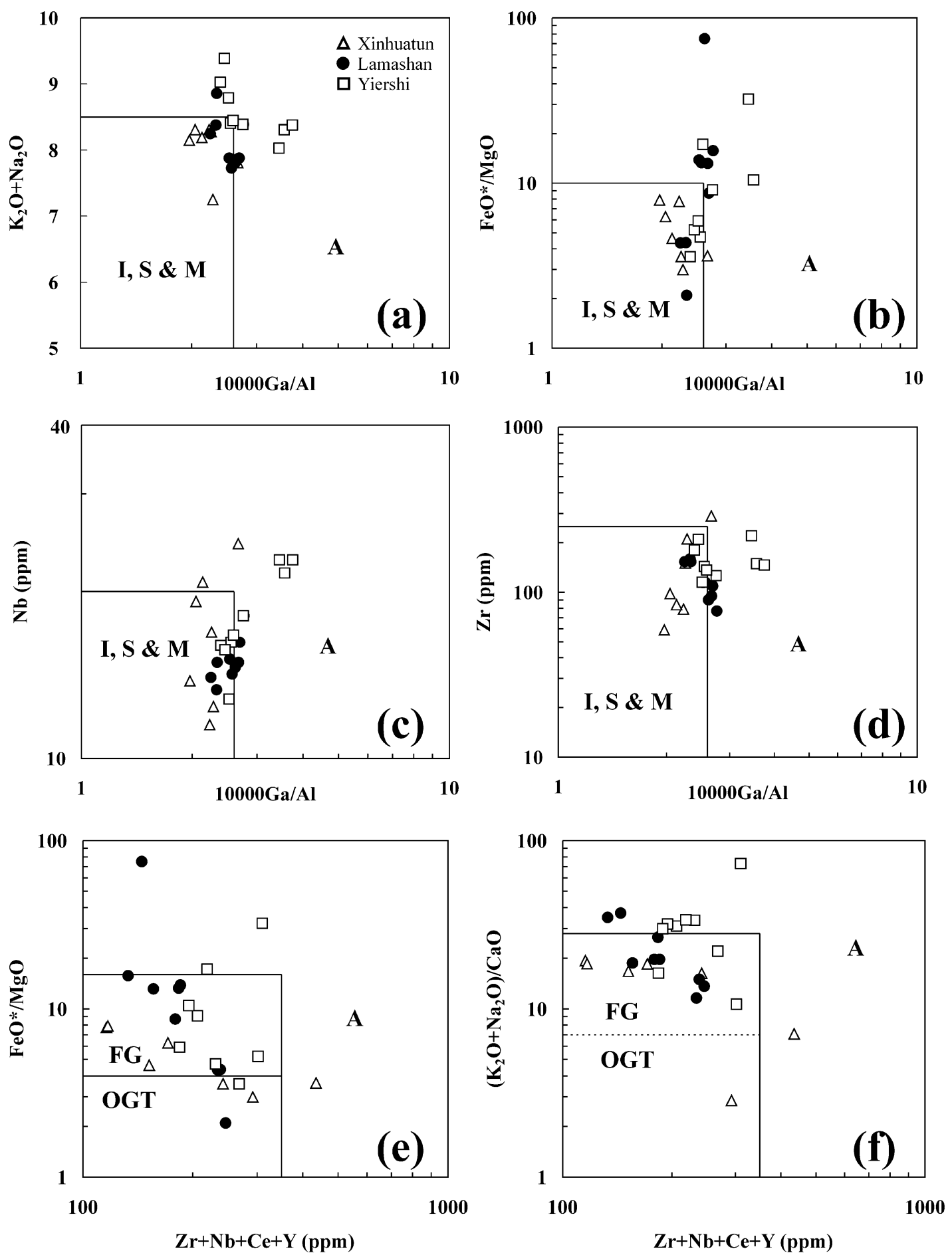

Fig. 13. (a) $\mathrm{K}_{2} \mathrm{O}+\mathrm{Na}_{2} \mathrm{O}$, (b) $\mathrm{FeO} * \mathrm{MgO}$, (c) $\mathrm{Nb}$, (d) $\mathrm{Zr}$ vs. $10000 \mathrm{Ga} / \mathrm{Al}$ and (e) $\mathrm{FeO} * \mathrm{MgO}$, (f) $\left(\mathrm{K}_{2} \mathrm{O}+\mathrm{Na} \mathrm{O}_{2} \mathrm{O}\right) / \mathrm{CaO}$ vs. $(\mathrm{Zr}+\mathrm{Nb}+\mathrm{Ce}+\mathrm{Y})$ classification diagrams (Whalen et al., 1987), indicating that the granites from NE China are transitional between the I-, S-, M- and A-types (ad) or highly fractionated. FG: Fractionated felsic granites; OGT: unfractionated M-, I- and S-type granites. 
constant at about $200 \mathrm{ppm}$. In log-log diagrams of $\mathrm{Ba}$ vs. $\mathrm{Sr}$ and $\mathrm{Ba} / \mathrm{Sr}$ vs. Sr (Fig. 14), it appears that $\mathrm{Sr}$ concentration decreases sharply from about 500 to $<10 \mathrm{ppm}$, whereas $\mathrm{Ba}$ changes little in the early stage of crystallization but decreases rapidly in the later stage. This is explained by fractionation of plagioclase in the early stage, and by separation of plagioclase and biotite, rather than K-feldspar, in later stages, because the proportion of K-feldspar increases during magmatic evolution as shown by the petrography (Table 1). Low $\mathrm{MgO}$ content in these granites suggests separation of mafic minerals, and petrographic evidence favors a probable fractionation of biotite. The overall geochemical evolution is consistent with fractional crystallization from granodiorite, monzogranite, syenogranite to alkali-feld-

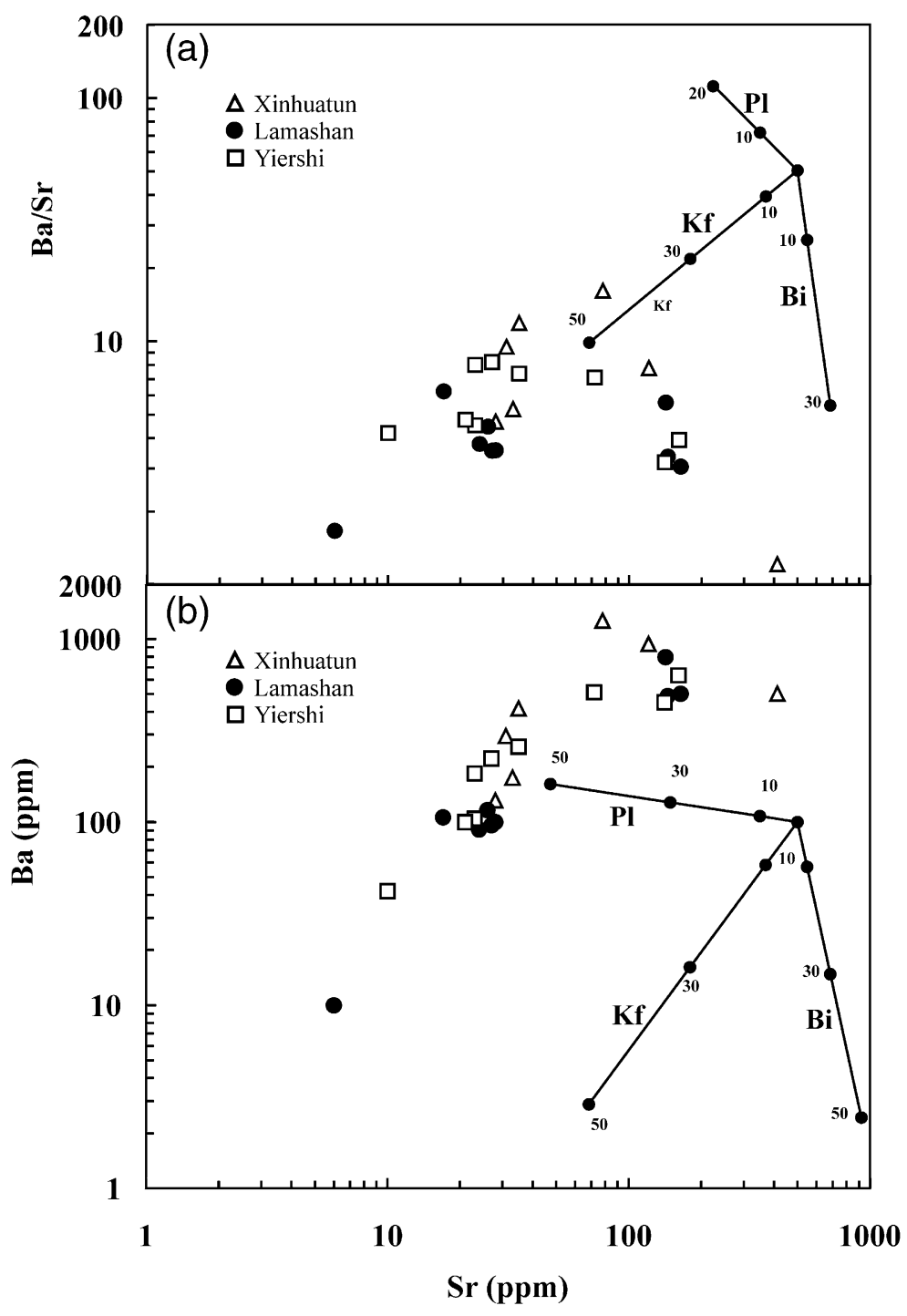

Fig. 14. (a) $\mathrm{Ba} / \mathrm{Sr}$ vs. Sr and (b) Ba vs. Sr diagrams showing that fractionation of plagioclase plays an important role in the early stage of differentiation; whereas in the later stage, separation of plagioclase and biotite, rather than K-feldspar alone, appears to have controlled the variation of these elements. Partition coefficients of $\mathrm{Sr}$ and $\mathrm{Ba}$ are from Hanson (1978). 
spar granite. Magma mixing or partial melting of heterogeneous sources is not required to explain the concentration patterns.

In addition to major phases, accessory minerals seem to have controlled much of the REE variation. The decrease of REE with increasing $\mathrm{SiO}_{2}$ suggests a separation of minerals with high partition coefficients $(\mathrm{Kd})$, such as apatite, titanite, zircon, allanite and monazite, which are important accessory minerals in these rocks. In a diagram of $(\mathrm{La} / \mathrm{Yb})_{\mathrm{N}}$ vs. La (Fig. 15), the variation of REE contents seems to be consistent with fractionation of allanite and monazite (less than $2 \%$ ) and, to a lesser extent, apatite. Zircon does not seem to have exerted much influence on REE fractionation. For Xinhuatun samples, the regular decrease in REE or La content from X-4 to X-2 to X-3 to X-1 is mimicked by regular decrease in $\mathrm{P}_{2} \mathrm{O}_{5}$ and Th concentrations (Table 2), which suggests a separation of monazite instead of allanite + apatite during the differentiation process.

The distinctive REE patterns of two Yiershi samples (YE-6 and YE-7, Fig. 4) are highly unusual. Although similar patterns in granites have been reported previously (Koljonen and Rosenberg, 1974), the precise mechanism for creating these patterns is not clear. Our simple modeling suggests that a greater separation of apatite, allanite, titanite and/or monazite was probably responsible. Hornblende was not observed in any of the samples, but it could have disappeared due to fractionation. The result of modeling is presented in Table 6. As shown in Fig. 16, separation of apatite and allanite would lower overall REE abundance, enhance the concavity of REE patterns and reduce the degree of Eu anomalies from the "parental" magma with strong negative Eu anomaly, as represented by sample YE-1. Due to the similar partition coefficients, fractionation of titanite would have the same effect as apatite. Monazite is not included in the simulation test, but its effect is similar to that of allanite, only to enhance the skewness of the concavity toward HREE.

In summary, during the formation of the various granites, fractionation of feldspars, biotite, apatite, monazite and ilmenite has played an important role. Fractionation of biotite and feldspars is the main cause for the variation of major elements. At the same time, feldspars also controlled $\mathrm{Rb}, \mathrm{Sr}$ and $\mathrm{Ba}$ abundances. The variation of REE was mainly

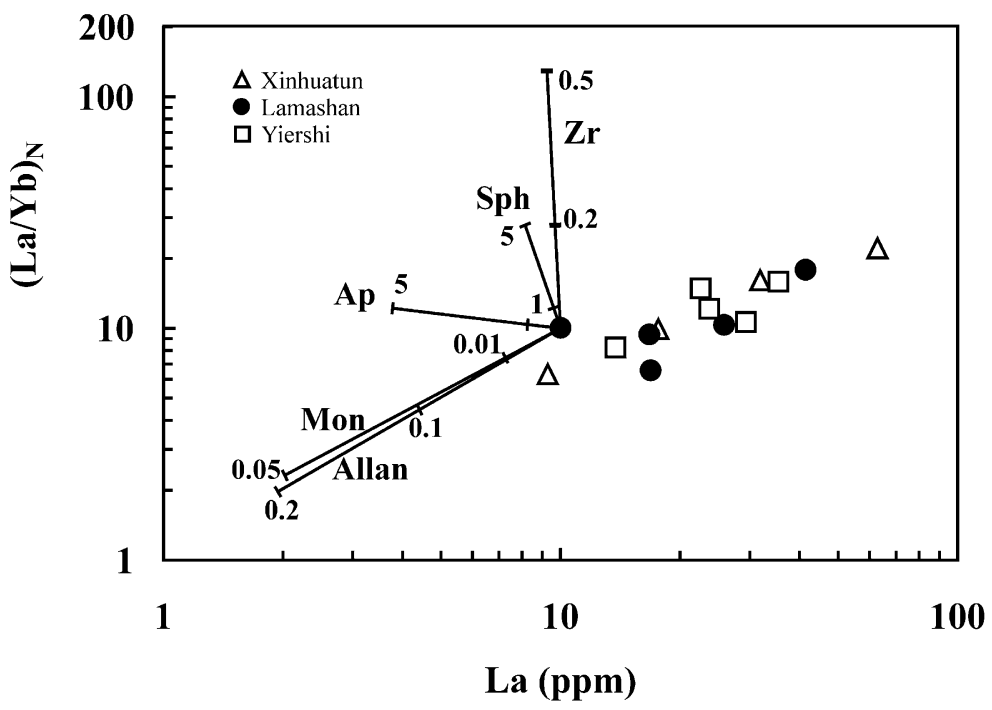

Fig. 15. $(\mathrm{La} / \mathrm{Yb})_{\mathrm{N}}$ vs. La diagram showing the change of REE patterns by separation of accessory minerals, especially allanite and apatite Partition coefficients are from Arth (1976) for apatite, Green and Pearson (1986) for titanite, Mahood and Hildreth (1983) for zircon, Green et al. (1989) for allanite and Yurimoto et al. (1990) for monazite. 
Table 6

Modelling of formation of concave REE patterns

\begin{tabular}{|c|c|c|c|c|c|c|c|c|c|c|c|c|c|c|}
\hline & \multirow{2}{*}{$\begin{array}{l}\mathrm{Kd} \\
(\mathrm{Hb})\end{array}$} & \multirow{2}{*}{$\begin{array}{l}\mathrm{Kd} \\
\text { (Ap) }\end{array}$} & \multirow{2}{*}{$\begin{array}{l}\mathrm{Kd} \\
(\mathrm{Aln})\end{array}$} & \multirow{2}{*}{$\begin{array}{l}\text { Kd } \\
\text { (Tit) }\end{array}$} & \multirow{2}{*}{$\begin{array}{l}\mathrm{D} \\
(\text { ApAln) } \\
(95 / 5)\end{array}$} & \multirow{2}{*}{$\begin{array}{l}\text { D } \\
\text { (HbApAln) } \\
(70 / 28.5 / 1.5)\end{array}$} & \multirow{2}{*}{$\begin{array}{l}\text { D } \\
\text { (ApAlnTit) } \\
(48 / 4 / 48)\end{array}$} & \multirow{2}{*}{$\begin{array}{l}\text { Co } \\
(\mathrm{YE} 1) \times \\
\text { chon }\end{array}$} & \multicolumn{6}{|c|}{$\mathrm{C}^{\mathrm{l}}=\mathrm{Co} . \mathrm{F}^{(\mathrm{D}-1)}$} \\
\hline & & & & & & & & & $\begin{array}{l}F=0.98 \\
(\text { ApAln) }\end{array}$ & $\begin{array}{l}F=0.99 \\
(\text { ApAln) }\end{array}$ & $\begin{array}{l}F=0.95 \\
(\text { HbApAln) }\end{array}$ & $\begin{array}{l}F=0.97 \\
(\text { HbApAln) }\end{array}$ & $\begin{array}{l}F=0.98 \\
\text { (ApAlnTit) }\end{array}$ & $\begin{array}{l}F=0.99 \\
(\text { ApAlnTit })\end{array}$ \\
\hline $\mathrm{La}$ & 0.75 & 30 & 1000 & 30 & 79 & 24 & 69 & 112.41 & 23.5 & 51.6 & 34.4 & 55.7 & 28.6 & 56.9 \\
\hline $\mathrm{Ce}$ & 1.4 & 40 & 1050 & 42 & 91 & 28 & 81 & 78.65 & 12.9 & 32.0 & 19.6 & 34.4 & 15.5 & 35.1 \\
\hline $\mathrm{Nd}$ & 4 & 55 & 900 & 60 & 97 & 32 & 91 & 32.87 & 4.7 & 12.5 & 6.7 & 12.8 & 5.3 & 13.3 \\
\hline Sm & 8 & 60 & 700 & 75 & 92 & 33 & 93 & 16.89 & 2.7 & 6.8 & 3.2 & 6.3 & 2.6 & 6.7 \\
\hline $\mathrm{Eu}$ & 5 & 40 & 50 & 70 & 41 & 16 & 55 & 3.92 & 1.8 & 2.6 & 1.8 & 2.5 & 1.3 & 2.3 \\
\hline Gd & 11 & 60 & 400 & 75 & 77 & 31 & 81 & 8.83 & 1.9 & 4.1 & 1.9 & 3.6 & 1.8 & 4.0 \\
\hline Dy & 12 & 50 & 200 & 70 & 58 & 26 & 66 & 5.98 & 1.9 & 3.4 & 1.7 & 2.8 & 1.6 & 3.1 \\
\hline $\mathrm{Er}$ & 10 & 40 & 150 & 60 & 46 & 21 & 54 & 5.54 & 2.3 & 3.5 & 2.0 & 3.0 & 1.9 & 3.3 \\
\hline $\mathrm{Yb}$ & 8 & 20 & 90 & 50 & 24 & 13 & 37 & 7.07 & 4.5 & 5.6 & 3.9 & 5.0 & 3.4 & 4.9 \\
\hline $\mathrm{Lu}$ & 6 & 14 & 75 & 45 & 17 & 9 & 31 & 7.31 & 5.3 & 6.2 & 4.8 & 5.7 & 4.0 & 5.4 \\
\hline
\end{tabular}

Partition coefficients from Arth (1976), Hanson (1978) and estimates from the literature.

Abbreviations: $\mathrm{Hb}=$ hornblende, $\mathrm{Ap}=$ apatite, $\mathrm{Aln}=$ allanite, $\mathrm{Tit}=$ titanite, chon $=$ chondrite abundances. 

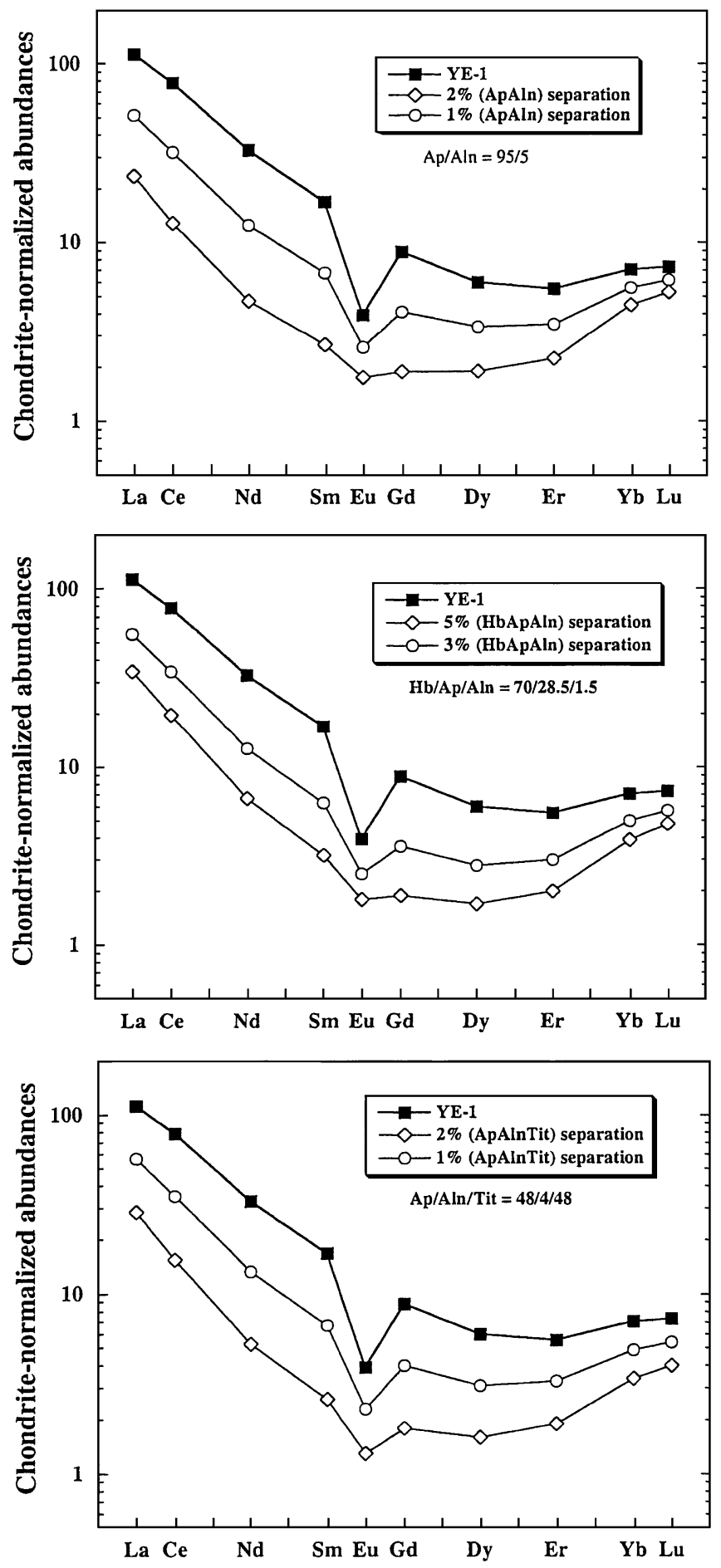

Fig. 16. REE patterns of sample YE-1 and modeled concave patterns with a variety of fractionated phase combinations. If the starting composition has a smaller negative Eu anomaly, such as that shown by YE-5 and YE-9 (Fig. 3), then this anomaly would disappear with the same degree of fractionation as indicated in the figure. 
achieved by fractionation of apatite, monazite and allanite. The primary magma was probably granodioritic in view of the lithological characters of the early-crystallized products in the Xinhuatun pluton. If the nature of the enclave suite is considered, it is equally possible that the primary magma was dioritic. However, the extensive mineral fractionation makes the assessment of primary magma composition highly uncertain.

\section{Conclusions}

The present study leads to the following conclusions:

(1) The three studied plutons in NE China (Xinhuatun, Lamashan and Yiershi) range from granodiorite (minor), monzogranite, syenogranite to alkali-feldspar granite in lithology. The petrography is characterized by quartz and perthitic feldspar as the principal mineral phases with minor amounts of plagioclase, biotite and some accessory minerals.

(2) Zircon U-Pb SHRIMP analyses indicate that these granites were emplaced in the Jurassic (184-137 Ma), not Triassic as previously thought. BiotiteWR $\mathrm{Rb}-\mathrm{Sr}$ isochrons and ${ }^{40} \mathrm{Ar} /{ }^{39} \mathrm{Ar}$ ages of feldspars suggest that they have undergone a slow cooling history, which allows extensive fractional crystallization.

(3) Geochemical study indicates that the granites are silica-rich, peraluminous and have high contents of alkalis and evident enrichment of light relative to heavy REE, with significant negative $\mathrm{Eu}$ anomalies. The negative anomalies of $\mathrm{Ba}, \mathrm{Nb}$, $\mathrm{Sr}, \mathrm{P}, \mathrm{Eu}$ and $\mathrm{Ti}$, and positive anomaly of $\mathrm{Pb}$ in the spidergram, suggest that these granites have undergone advanced fractional crystallization with separation of plagioclase, biotite, K-feldspar and accessory minerals. Genetically, they are highly fractionated I-types.

\section{Acknowledgements}

Fuyuan $\mathrm{Wu}$ is most grateful to the laboratory staff in Rennes, particularly to Odile Henin, Joél Macé,
Nicole Morin and Martine Le Coz-Bouhnik for their instructions in chemical separation, mass spectrometry and XRF analyses. R. Capdevila, Jon Patchett, M. Wilson, H.-J. Forster, Alain Cocherie and O. T. Rämö commented on earlier drafts and provided many useful suggestions. This work was supported by the National Natural Science Foundation of China (NSFC grant 4940008 to Q. Lin and 49872031 to F.Y. Wu), the State Education Commission of China (to F.Y. Wu for his stay in France) and French research programmes of "Dynamique des Transferts Terrestres" (INSU-DTT 97) and "Cycles Géochimiques" (INSUIT 99) granted to B.M. Jahn. This is INSU Contribution No. 327. The SHRIMP facility in Perth is operated by the Western Australian Consortium, comprising Curtin University of Technology, the University of Western Australia and the Geological Survey of Western Australia. This paper is also a contribution to IGCP-420: Crustal Growth in the Phanerozoic: Evidence from Central Asia.

\section{References}

Arth, J.G., 1976. Behaviour of trace elements during magmatic processes: a summary of theoretical models and their applications. J. Res. U.S. Geol. Surv. 4, 41-47.

Champion, D.C., Chappell, B.W., 1992. Petrogenesis of felsic I-type granites: an example from northern Queensland. Trans. R. Soc. Edinb. Earth Sci. 83, 115-126.

Chappell, B.W., Stephens, W.E., 1988. Origin of infracrustal (I-type) granite magmas. Trans. R. Soc. Edinb. Earth Sci. 79, $71-86$.

Chappell, B.W., White, A.J.R., 1974. Two contrasting granite types. Pac. Geol. 8, 173-174.

Chappell, B.W., White, A.J.R., 1992. I- and S-type granites in the Lachlan Fold Belt. Trans. R. Soc. Edinb. Earth Sci. 83, 1-26.

Chappell, B.W., White, A.J.R., 2001. Two contrasting granite types: 25 years later. Aust. J. Earth Sci. 48, 489-499.

Chappell, B.W., White, A.J.R., Williams, I.S., Wyborn, D., Wyborn, L.A., 2000. Lachlan fold belt granites revisited: highand low-temperature granites and their implications. Aust. J. Earth Sci. 47, 123-138.

Collins, W.J., Beams, S.D., White, A.J.R., Chappell, B.W., 1982. Nature and origin of A-type granites with particular reference to southeastern Australia. Contrib. Mineral. Petrol. 80, 189-200.

Compston, W., Williams, I.S., Kirschvink, J.L., Zhang, Z., Ma, G., 1992. Zircon $\mathrm{U}-\mathrm{Pb}$ ages for the Early Cambrian time-scale. J. Geol. Soc. (London) 149, 171-184.

Eby, G.N., 1990. The A-type granitoids: a review of their occurrence and chemical characteristics and speculations on their petrogenesis. Lithos 26, 115-134. 
Eby, G.N., 1992. Chemical subdivision of the A-type granitoids: petrogenetic and tectonic implications. Geology 20, 641-644.

Fang, W.C., 1992. The Granitoids and Their Mineralizations in Jilin Province (in Chinese). Jilin Publishing House of Science and Technology, Changchun. 271 pp.

Green, T.H., Pearson, N.J., 1986. Rare-earth element partitioning between titanite and coexisting silicate liquid at high pressure and temperature. Chem. Geol. 55, 105-119.

Green, T.H., Sie, S.H., Ryan, C.G., Cousens, D.R., 1989. Proton microprobe-determined partitioning of $\mathrm{Nb}, \mathrm{Ta}, \mathrm{Zr}, \mathrm{Sr}$ and $\mathrm{Y}$ between garnet, clinopyroxene and basaltic magma at high pressure and temperature. Chem. Geol. 74, 201-216.

Han, B.F., Wang, S.G., Jahn, B.M., Hong, D.W., Kagami, H., Sun, Y.L., 1997. Depleted-mantle magma source for the Ulungur River A-type granites from north Xinjiang, China: geochemistry and $\mathrm{Nd}-\mathrm{Sr}$ isotopic evidence, and implication for Phanerozoic crustal growth. Chem. Geol. 138, 135-159.

Hanson, G.N., 1978. The application of trace elements to the petrogenesis of igneous rocks of granitic composition. Earth Planet. Sci. Lett. 38, 26-43.

Harrison, M.T., 1990. Some observations on the interpretation of feldspar ${ }^{40} \mathrm{Ar} /{ }^{39} \mathrm{Ar}$ results. Chem. Geol. 80, 219-229.

HBGMR (Heilongjiang Bureau of Geology and Mineral Resources), 1993. Regional Geology of Heilongiiang Province (in Chinese with English summary). Geological Publishing House, Beijing, pp. 347-438.

Hong, D.W., Huang, H.Z., Xiao, Y.J., Xu, H.M., Jin, M.Y., 1994. The Permian alkaline granites in central Inner Mongolia and their geodynamic significance. Acta Geol. Sin. 68, 219-230.

IMBGMR (Inner Mongolian Bureau of Geology and Mineral Resources), 1990. Regional Geology of Inner Mongolian Autonomous Region (in Chinese with English summary). Geological Publishing House, Beijing. 725 pp.

Jager, E., Niggli, E., Wenk, E., 1967. Rb-Sr altersbestimmungen an glimmern der zentralalpen. Beitr. Geol. Karte Shweiz N. F. $134,1-67$.

Jahn, B.M., Cornichet, J., Cong, B.L., Yui, T.F., 1996. Ultrahigh$\varepsilon_{\mathrm{Nd}}$ eclogites from an ultrahigh-pressure metamorphic terrane of China. Chem. Geol. 127, 61-79.

Jahn, B.M, Wu, F.Y, Capdevila, R., Fourcade, S., Wang, Y.X., Zhao, Z.H., 2001. Highly evolved juvenile granites with tetrad REE patterns: the Woduhe and Baerzhe granites from the Great Xing'an (Khingan) Mountains in NE China. Lithos 59, $171-198$.

JBGMR (Jilin Bureau of Geology and Mineral Resources), 1988. Regional Geology of Jilin Province (in Chinese with English summary). Geological Publishing House, Beijing, pp. 301-385.

King, P.L., White, A.J.R., Chappell, B.W., Allen, C.M., 1997. Characterization and origin of aluminous A-type granites from the Lachlan Fold Belt, Southeastern Australia. J. Petrol. 38, 371-391.

King, P.L., Chappell, B.W., Allen, C.M., White, A.J.R., 2001. Are A-type granites the high-temperature felsic granites? Evidence from fractionated granites of the Wangrah Suite. Aust. J. Earth Sci. 48, 501-514

Koljonen, T., Rosenberg, R.J., 1974. Rare earth elements in granitic rocks. Lithos 7, 249-261.
Landenberger, B., Collins, W.J., 1996. Derivation of A-type granites from a dehydrated charnockitic lower crust: evidence from the Chaelundi complex, eastern Australia. J. Petrol. 37, 145-170.

Li, P.Z., Yu, J.S., 1993. Nianzishan miarolitic alkaline granite stock, Heilongjiang - its ages and geological implications (in Chinese with English abstract). Geochimica 22, 389-398.

Li, Z.T., Zhao, C.J., 1984. On the regularity of the tempo-spatial distribution of the granitic rocks in the northern part of northeast China. In: Xu, K.Q., Tu, G.C. (Eds.), Geology of Granites and their Metallogenetic Relations. Science Press, Beijing, pp. 195-209.

Lo, C.-H., Lee, C.Y., $1994 .{ }^{40} \mathrm{Ar} /{ }^{39} \mathrm{Ar}$ method of $\mathrm{K}-\mathrm{Ar}$ age determination of geological samples using Tsing-Hua Open-pool (THOR) Reactor. J. Geol. Soc. China 37, 143-164.

Loiselle, M.C., Wones, D.R., 1979. Characteristics and origin of anorogenic granites. Geol. Soc. Am., Prog. Abstr. 11, 468.

Ludwig, K.R., 1999. Isoplot/Ex (v. 2.06)-A Geochronological Toolkit for Microsoft Excel. Spec. Publ., vol. 1a. Berkeley Geochronology Center. 49 pp.

Mahood, G., Hildreth, W., 1983. Large partition coefficients for trace elements in high-silica rhyolites. Geochim. Cosmochim. Acta 47, 11-30.

McDougall, I., Harrison, T.M., 1988. Geochronology and Thermochronology by the ${ }^{40} \mathrm{Ar} /{ }^{39} \mathrm{Ar}$ Method. Oxford Univ. Press, New York. 212 pp.

Nelson, D.R., 1999. Compilation of geochronology data, 1998, Geological Survey of Western Australia Record 1999/2, 218 pp.

Odin, G.S. et al., 1982. Interlaboratory standards for dating purpose. In: Odin, G.S. (Ed.), Numerical Dating in Stratigraphy. Wiley, Chichester, UK, pp. 123-149.

Pidgeon, R.T., Furfaro, D., Kennedy, A.K., Nemchin, A.A., van Bronswijk, W., Todt, W.A., 1994. Calibration of zircon standards for the Curtin SHRIMP II. Eighth International Conference on Geochronology, Cosmochronology and Isotope Geology, Berkeley, June 5-11. University of California, Berkeley, p. 251. Abstracts.

Pitcher, W.S., 1982. Granite type and tectonic environment. In: Hsu, K.J. (Ed.), Mountain Building Processes. Academic Press, London, pp. 19-40.

Pitcher, W.S., 1993. The Nature and Origin of Granite Blackie Academic and Professional, London. $321 \mathrm{pp}$.

Qin, K.Z., Tanaka, R., Li, W.S., Ishihara, S., 1998. The discovery of Indosinian granites in Manzhouli area: evidence from $\mathrm{Rb}-\mathrm{Sr}$ isochrons (in Chinese with English abstract). Acta Petrol. Mineral. 17, 235-240.

Qin, K.Z., Li, H.M., Li, W.S., Ishihara, S., 1999. Intrusion and mineralization ages of the Wulugetushan porphyry $\mathrm{Cu}-\mathrm{Mo}$ deposit, Inner Mongolia, northeastern China (in Chinese with English abstract). Geol. Rev. 45, 180-185.

Sengör, A.M.C., Natal'in, B.A., 1996a. Paleotectonics of Asia: fragments of a synthesis. In: Yin, A., Harrison, M. (Eds.), The Tectonic Evolution of Asia. Cambridge Univ. Press, New York, pp. $486-640$.

Sengör, A.M.C., Natal'in, B.A., 1996b. Turkic-type orogeny and its role in the making of the continental crust. Annu. Rev. Earth Planet. Sci. 24, 263-337. 
Sengör, A.M.C., Natal'in, B.A., Burtman, V.S., 1993. Evolution of the Altaid tectonic collage and Palaeozoic crustal growth in Eurasia. Nature 364, 299-307.

Steiger, R.H., Jäger, E., 1977. Subcommission on geochronology: convention on the use of decay constants in geo- and cosmochronology. Earth Planet. Sci. Lett. 36, 359-362.

Sun, S.S., McDonough, W.F., 1989. Chemical and isotopic systematics of oceanic basalts: implications for mantle composition and processes. In: Saunders, A.D., Norry, M.J. (Eds.), Magmatism in the Ocean Basins. Geol. Soc. Spec. Publ., vol. 42, pp. 313-345.

Sun, D.Y., Wu, F.Y., Li, H.M., Lin, Q., 2001. Emplacement age of the postorogenic A-type granites in northwestern Lesser Xing'an Ranges, and its relationship to the eastward extension of Suolunshan-Hegenshan-Zhalaite collisional suture zone. Chin. Sci. Bull. 46, 427-432.

Sylvester, P.J., 1989. Post-collisional alkaline granites. J. Geol. 97 , $261-280$.

Tang, K.D., 1990. Tectonic development of Palaeozoic fold belts at the north margin of the Sino-Korean craton. Tectonics 9, 249-260.

Tang, K.D., Wang, Y., He, G.Q., Shao, J.A., 1995. Continentalmargin structure of northeast China and its adjacent areas (in Chinese with English abstract). Acta Geol. Sin. 69, 16-30.

Wang, Y.X., Zhao, Z.H., 1997. Geochemistry and origin of the Baerzhe REE- $\mathrm{Nb}-\mathrm{Be}-\mathrm{Zr}$ superlarge deposit (in Chinese with English abstract). Geochimica 26, 24-35.

Wang, S.G., Han, B.F., Hong, D.W., Xu, B.L., Sun, Y.Y., 1994. Geochemistry and tectonic significance of alkali granites along Ulungur River, Xinjiang (in Chinese with English abstract). Sci. Geol. Sin. 29, 373-383.

Whalen, J.B., Currie, K.L., Chappell, B.W., 1987. A-type granites: geochemical characteristics, discrimination and petrogenesis. Contrib. Mineral. Petrol. 95, 407-419.

Whalen, J.B., Jenner, G.A., Longstaffe, F.J., Robert, F., Gariepy, C., 1996. Geochemical and isotopic $(\mathrm{O}, \mathrm{Nd}, \mathrm{Pb}$ and $\mathrm{Sr})$ constraints on A-type granite: petrogenesis based on the Topsails igneous suite, Newfoundland Appalachians. J. Petrol. 37, 1463-1489.

White, A.J.R., Chappell, B.W., 1983. Granitoid types and their distribution in the Lachlan Fold Belt, southeastern Australia. In: Roddick, J.A. (Ed.), Circum-Pacific Plutonic Terranes. Geol. Soc. Am., Mem., vol. 159, pp. 21-34.

Wilde, S.A., Dorsett-Bain, H.L., Liu, J.L., 1997. The identification of a Late Pan-African granulite facies event in northeastern China: SHRIMP U-Pb zircon dating of the Mashan Group at Liu Mao, Heilongjiang Province, China. Proc. 30th IGC: Precambrian Geol. Metamorphic Petrol., vol. 17. VSP International Publisher, Amsterdam, pp. 59-74.
Wilde, S., Zhang, X.Z., Wu, F.Y., 2000. Extension of a newly identified $500 \mathrm{Ma}$ metamorphic terrain in North East China: further U-Pb SHRIMP dating of the Mashan Complex, Heilongiiang Province, China. Tectonophysics 328, 115-130.

Williams, I.S., 1998. U-Th-Pb geochronology by ion microprobe. In: McKibben, M.A., Shanks III., W.C., Ridley, W.I. (Eds.), Applications of microanalytical techniques to understanding mineralizing processes. Rev. Econ. Geol., vol. 7, pp. 1-35.

Wu, F.Y., Ye, M., Zhang, S.H., 1995. The geodynamic model of the Manzhouli-Suifenghe geoscience transect (in Chinese with English abstract). J. Earth Sci. 20, 535-539.

Wu, F.Y., Jahn, B.M., Wilde, S., Sun, D.Y., 2000. Phanerozoic crustal growth: $\mathrm{U}-\mathrm{Pb}$ and $\mathrm{Sr}-\mathrm{Nd}$ isotopic evidence from the granites in northeastern China. Tectonophysics 328, 89-113.

Wu, F.Y., Sun, D.Y., Li, H.M., Wang, X.L., 2001. The nature of basement beneath the Songliao Basin in NE China: geochemical and isotopic constraints. Phys. Chem. Earth (Part A) 26, $793-803$.

Wu, F.Y., Sun, D.Y., Li, H.M., Jahn, B.M., Wilde, S.A., 2002. Atype granites in northeastern China: age and geochemical constraints on their petrogenesis. Chem. Geol. 187, 143-173.

Ye, M., Zhang, S.H., Wu, F.Y., 1994. The classification of the Paleozoic tectonic units in the area crossed by Manzhouli-Suifenghe geoscience transect (in Chinese with English abstract). J. Changchun Univ. Earth Sci. 24, 241-245.

York, D., 1969. Least-squares fitting of a straight line with correlated errors. Earth Planet. Sci. Lett. 5, 320-324.

Yu, J.J., Xu, Z.G., Xu, F.S., 1996. Tectonic setting of Ordovician volcanic rocks in northwestern Xiaoxing'anling, Heilongjiang Province (in Chinese with English abstract). Acta Geosci. Sin. $17,54-64$.

Yurimoto, H., Duke, E.F., Papike, J.J., Shearer, C.K., 1990. Are discontinuous chondrite-normalized REE patterns in pegmatitic granite systems the results of monazite fractionation? Geochim. Cosmochim. Acta 54, 2141-2145.

Zhang, X.Z., 1992. Heilongjiang melange: the evidence of Caledonian suture zone of the Jiamusi massif (in Chinese with English abstract). J. Changchun Univ. Earth Sci. 22, 94-101 (Special Issue: Doctoral thesis).

Zhao, X.X., Coe, R.S., Zhou, Y.X., Wu, H.R., Wang, J., 1990. New paleomagnetic results from northern China: collision and suturing with Siberia and Kazakhstan. Tectonophysics 181, 43-81.

Zonenshain, L.P., Kuzmin, M.I., Kononov, M.V., 1985. Absolute reconstructions of the Paleozoic oceans. Earth Planet. Sci. Lett. 74, $103-116$.

Zonenshain, L.P., Kuzmin, M.I., Natapov, L.M., 1990. Geology of the USSR: A Plate Tectonic Synthesis. Geodyn. Ser., vol. 21. Am. Geophys. Union, Washington, DC. 242 pp. 